\title{
$\mathrm{CoO}-\mathrm{MgO} \mathrm{Cr}_{2} \mathrm{O}_{3}-\mathrm{TiO}_{2}-\mathrm{SnO}_{2}$ 系 スピネル固溶体の生成と色
}

\author{
大、潒淳。藤 橋 雄一郎 \\ (横浜国立大学 工学部)
}

\section{Formation and Color of the Spinel Solid Solution in $\mathrm{CoO}-\mathrm{MgO}-\mathrm{Cr}_{2} \mathrm{O}_{3}-\mathrm{TiO}_{2}-\mathrm{SnO}_{2}$ System}

By

Atsushi OHTSUKA and Yuhichiroh FUJIHASHI

(Faculty of Engineering, Yokohama National University)

This study was concerned with the formation, color development and application for colored glazes of the spinel solid solution in $\mathrm{CoO}-\mathrm{MgO}-\mathrm{Cr}_{2} \mathrm{O}_{3}-\mathrm{TiO}_{2}-\mathrm{SnO}_{2}$ system.

Specimens were prepared by calcining the oxide mixtures at $1400^{\circ} \mathrm{C}$ for $1 \mathrm{hr}$. Concerning each specimens, the formation of spinel solid solution was investigated by $\mathrm{X}$-ray diffraction, the color was discussed by means of spectral reflectance and the stability for various glazes was tested. The results were summarized as follows.

1. A formation of continuous solid solution and an obedience to Vegard's law were confirmed by $\mathrm{X}$-ray analysis.

2. In $\mathrm{MgO}-\mathrm{Cr}_{2} \mathrm{O}_{3}-\mathrm{TiO}_{2}-\mathrm{SnO}_{2}$ system, as the amount of $\mathrm{Cr}^{3+}$ increased, color ranged from yellow green through leaf to grayish leaf, and the absorption of $\mathrm{Cr}^{3+}$ shifted towards violet region.

3. Colors which developed in $\mathrm{CoO}-\mathrm{MgO}-\mathrm{Cr}_{2} \mathrm{O}_{3}-\mathrm{SnO}_{2}$ system ranged from blue to bluish green, and the absorption of $\mathrm{Cr}^{3+}$ shifted towards violet region with increasing amount of $\mathrm{Cr}^{3+}$.

4. As the amount of $\mathrm{Cr}^{3+}$ increased, colors obtained in $\mathrm{CoO}-\mathrm{MgO}-\mathrm{Cr}_{2} \mathrm{O}_{3}-\mathrm{TiO}_{2}$ system, ranged from bluish green through green to bluish green, and the absorption of $\mathrm{Co}^{2+}$ and $\mathrm{Cr}^{3+}$ shifted towards violet region.

5. $\mathrm{CoO}-\mathrm{MgO}-\mathrm{TiO}_{2}-\mathrm{SnO}_{2}$ system revealed the colors ranging from blue to bluish green, and the absorption of $\mathrm{Co}^{2+}$ shifted towards red region as the amount of $\mathrm{Ti}^{4+}$ increased.

6. Colors ranging from bluish green to green developed in $\mathrm{CoO}-\mathrm{MgO}-\mathrm{Cr}_{2} \mathrm{O}_{3}-\mathrm{TiO}_{2}-$ $\mathrm{SnO}_{2}$ system.

7. According to the results of the colored glaze tests, the specimens with the composition in $\mathrm{Cr}^{3+}$ rich region were appreciated to be stable as a glaze stain.

[Received May 11, 1973]

\section{1. 緒言}

先に著者は，新らしい無機顔料の開発研究の一環とし $\tau, \mathrm{Co}^{2+}, \mathrm{Ni}^{2+}$ を置換固溶したチタンスピネル ${ }^{1) 22}$, 錫 スピネル ${ }^{3)}$ ～チタン一錫スピネル ${ }^{4)}$, チタンーアルミニ ウムスピネル吕执よびチタン一クロムスピネル につき， その生成と色とにつき報告し，錫一クロムスピネルマに おいては, 陶磁器への適用性について, 色釉の試験を行 ない，その結果を併せて報告した。 このほか，山口ら により, クロムスピネル, 錫スピネルの色, 格子定数, 陶磁器への適用性が検討されている。これらの結果を総 合すると, $\mathrm{CoO}-\mathrm{MgO}-\mathrm{SnO}_{2}$ 系の錫スピネルでは, いわ
ゆるセルリアンの青, $\mathrm{CoO}-\mathrm{MgO}-\mathrm{Cr}_{2} \mathrm{O}_{3}$ 系クロムスピ ネルでは青緑, $\mathrm{CoO}-\mathrm{MgO}-\mathrm{TiO}_{2}$ 系チタンスピネルでは やはり青緑の，いずれも鮮明な色調が得られ，さらに， $\mathrm{CoO}-\mathrm{MgO}-\mathrm{TiO}_{2}-\mathrm{SnO}_{2}, \mathrm{CoO}-\mathrm{MgO}-\mathrm{Cr}_{2} \mathrm{O}_{3}-\mathrm{TiO}_{2}, \mathrm{CoO}$ $-\mathrm{MgO}-\mathrm{Cr}_{2} \mathrm{O}_{3}-\mathrm{SnO}_{2}$ の各チタン一錫, チタン一クロム, 錫一クロム系のスピネル固溶体においても，スピネル配 合の場合, 連続的に固溶体が生成し，いずれも青から青 緑にかけての，鮮明な色調が得られている。本研究は， これらの結果を基礎にして, $\mathrm{CoO}-\mathrm{MgO}-\mathrm{Cr}_{2} \mathrm{O}_{3}-\mathrm{TiO}_{2}-$ $\mathrm{SnO}_{2}$ 系で, クロム, チタン, 錫の 3 種のスピネル間固 溶体の生成とその色とを調心゙, あわせて, 陶磁器への適 
用性を検討する目的で企画したものである。

\section{2. 実 験方 法}

\section{1 試料の調製}

各試料の組成は，図-1 の組成三角形に示すようにと り，各頂点のスピネルを， $x \mathrm{CoO}(2-x) \mathrm{MgOSnO}_{2}, x$ $\mathrm{CoO}(1-x) \mathrm{MgOCr}_{2} \mathrm{O}_{3}, x \mathrm{CoO}(2-x) \mathrm{MgOTiO}_{2}$ の組成 とし， $x=0,0.2,0.5$ および 1.0 の各 4 種とし, 合計 21 $\times 4=84$ 個のスピネルを調製した. 図-1 で，No. 1 16 の錫一クロムスピネルの辺，打よびこれと平行の線で は, $\mathrm{Mg}^{2+}+\mathrm{Sn}^{4+} \rightleftarrows 2 \mathrm{Cr}^{3+}$ の, No. 16 21 のチタンー クロムスピネルの辺, 掠よびこれと平行の線では, $\mathrm{Mg}^{2+}$ $+\mathrm{Ti}^{4+} \rightleftarrows 2 \mathrm{Cr}^{3+}$, No. 1 21 のチタン一錫スピネルの 辺，㧍よびこれと平行な線では, $\mathrm{Sn}^{4+} \rightleftarrows \mathrm{Ti}^{4+}$ の各形式 の置換が行なわれる。試料調製に際し， $\mathrm{CoO}, \mathrm{MgO}$, $\mathrm{Cr}_{2} \mathrm{O}_{3}, \mathrm{TiO}_{2}$ および $\mathrm{SnO}_{2}$ は，いずれも酸化物の 1 級 試薬を使用した。混合は湿式で行ない, 乾燥後, 炭化珪 素発熱体電気炉中で加熱, 最高温度 $1400^{\circ} \mathrm{C}$ で 1 時間保 持した，加熱後放冷，粉砕し，次の各測定，および試験 を行なった。

\section{2 測定方法}

（1） X線分析，自記式 X線回折装置により， $\mathrm{CuK}_{\alpha}$ 線で単一スピネルの生成を調へ，格子定数を算出した。 格子定数は, この系のスピネルで約 $2 \theta=120 \sim 131^{\circ} に$ あらわれるスピネル (844) の面の回折ピークの角度を, 高純度 $\mathrm{Si}(99.999 \%)$ の (620) の面の回折ピーク $(d=$ $\left.0.85866 \AA 0 \alpha_{1}=127.554^{\circ}\right)$ で補正, また, $\mathrm{FeK}_{\alpha}$ 線の 場合は，約 $2 \theta=78 \sim 83^{\circ}$ 間に生じるスピネル (440) の 面の回折ピークを, $\mathrm{Si}(400)$ の回折ピーク $(d=1.35766$ $\left.\AA ， \alpha_{1}=80.606^{\circ}\right)$ で補正し, 求めた。

（2） 分光分析, 自記式分光光度計に上り, 400 760 $\mathrm{m} \mu$ 間の分光反射率曲線を求め, $\mathrm{Co}^{2+}, \mathrm{Cr}^{3+}$ の吸収と, その移動を観察し，色調を CIE の表示法で示した.ま た, 色名は, 日本色彩研究所編の調查用カラー・コード によった。

（3）色釉試験, 調製したスピネルの陶磁器への適用 性を検討するため，木節粘土 $33 \% ，$ 長石 $10 \%$ ，蝋石 $15 \%$ ，陶石 $42 \%$ （いずれも $\mathrm{wt} \%$ ）の半磁器質の素地を 円板状に加圧成形し， $700^{\circ} \mathrm{C}$ に加熱して得られた素地表 面上に，後に示す 3 種の釉を用い，釉に対しスピネルを $8 \%$ 加えて混合, 施釉後加熱し, 最高温度 $1300^{\circ} \mathrm{C}$ に 10 分間保持，放冷後，(1),(2) と同様の測定により，スピ ネルが残存しているか否かを観察し，同時に測色を行な った.

\section{3. 実 験 結 果}

調製した試料の組成，格子定数，測色結果を表-1，2， および図-1～14，色釉試験で用いた釉の組成を表-3，そ の結果を表-4, 5 亿示す. 表中, 試料の組成を示す際,

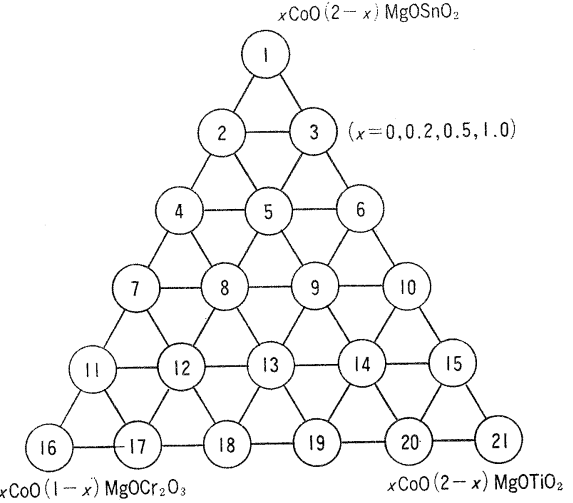

Fig. 1. Mole composition of specimens.

Table 1. Spinel solid solutions in $\mathrm{MgO}-\mathrm{Cr}_{2} \mathrm{O}_{3}-\mathrm{TiO}_{2}-\mathrm{SnO}_{2}$ system.

\begin{tabular}{|c|c|c|c|c|c|c|c|c|}
\hline No. & Composition & $x$ & $y$ & $\lambda_{D}(\mathrm{~m} \mu)$ & $P_{e}(\%)$ & $Y(\%)$ & Color & Lattice constant ( $\AA$ ) \\
\hline 1 & $\mathrm{M}_{2} \mathrm{~S}$ & 0.307 & 0.312 & 470.0 & 1.7 & 88.4 & bluish white & 8.637 \\
\hline 2 & $\mathrm{M}_{1.8} \mathrm{~S}_{0.8} \mathrm{Cr}_{0.2}$ & 0.332 & 0.388 & 563.3 & 25.0 & 43.0 & light yellow green & 8.577 \\
\hline 3 & $\mathrm{M}_{2} \mathrm{~S}_{0.8} \mathrm{~T}_{0.2}$ & 0.308 & 0.313 & 465.0 & 1.2 & 89.2 & purplish white & 8.601 \\
\hline 4 & $\mathrm{M}_{1.6} \mathrm{~S}_{0.6} \mathrm{Cr}_{0.4}$ & 0.332 & 0.398 & 562.2 & 27.8 & 33.6 & leaf & 8.515 \\
\hline 5 & $\mathrm{M}_{1.8} \mathrm{~S}_{0.6} \mathrm{~T}_{0.2} \mathrm{Cr}_{0.2}$ & 0.326 & 0.390 & 560.4 & 24.0 & 49.9 & light yellow green & 8.538 \\
\hline 6 & $\mathrm{M}_{2} \mathrm{~S}_{0.6} \mathrm{~T}_{0.4}$ & 0.309 & 0.315 & 477.0 & 0.6 & 85.7 & bluish white & 8.567 \\
\hline 7 & $\mathrm{M}_{1.4} \mathrm{~S}_{0.4} \mathrm{Cr}_{0.6}$ & 0.330 & 0.383 & 563.2 & 23.2 & 36.8 & leaf & 8.453 \\
\hline 8 & $\mathrm{M}_{1.6} \mathrm{~S}_{0.4} \mathrm{~T}_{0.2} \mathrm{Cr}_{0.4}$ & 0.329 & 0.405 & 560.2 & 28.9 & 33.7 & leaf & 8.472 \\
\hline 9 & $\mathrm{M}_{1.8} \mathrm{~S}_{0.4} \mathrm{~T}_{0.4} \mathrm{Cr}_{0.2}$ & 0.324 & 0.394 & 559.0 & 24.7 & 40.9 & light yellow green & 8.497 \\
\hline 10 & $\mathrm{M}_{2} \mathrm{~S}_{0.4} \mathrm{~T}_{0.6}$ & 0.309 & 0.317 & 499.0 & 0.4 & 83.8 & bluish white & 8.526 \\
\hline 11 & $\mathrm{M}_{1.2} \mathrm{~S}_{0.2} \mathrm{Cr}_{0.8}$ & 0.323 & 0.366 & 562.0 & 16.9 & 38.9 & grayish leaf & 8.388 \\
\hline 12 & $\mathrm{M}_{1.4} \mathrm{~S}_{0.2} \mathrm{~T}_{0.2} \mathrm{Cr}_{0.6}$ & 0.329 & 0.394 & 561.2 & 26.0 & 35.3 & leaf & 8.412 \\
\hline 13 & $\mathrm{M}_{1.6} \mathrm{~S}_{0.2} \mathrm{~T}_{0.4} \mathrm{Cr}_{0.4}$ & 0.326 & 0.399 & 559.5 & 26.6 & 35.9 & leaf & 8.435 \\
\hline 14 & $\mathrm{M}_{1.8} \mathrm{~S}_{0.2} \mathrm{~T}_{0.6} \mathrm{Cr}_{0.2}$ & 0.324 & 0.393 & 559.0 & 24.3 & 40.5 & light yellow green & 8.460 \\
\hline 15 & $\mathrm{M}_{2} \mathrm{~S}_{0.2} \mathrm{~T}_{0.8}$ & 0.310 & 0.318 & 548.0 & 0.4 & 84.4 & white & 8.485 \\
\hline 16 & $\mathrm{MCr}$ & 0.315 & 0.344 & 558.0 & 8.8 & 39.0 & grayish leaf & 8.333 \\
\hline 17 & $\mathrm{M}_{1.2} \mathrm{~T}_{0.2} \mathrm{Cr}_{0.8}$ & 0.331 & 0.393 & 562.3 & 26.3 & 29.6 & leaf & 8.355 \\
\hline 18 & $\mathrm{M}_{1.4} \mathrm{~T}_{0.4} \mathrm{Cr}_{0.6}$ & 0.329 & 0.394 & 561.3 & 26.0 & 32.6 & leaf & 8.375 \\
\hline 19 & $\mathrm{M}_{1.6} \mathrm{~T}_{0.6} \mathrm{Cr}_{0.4}$ & 0.330 & 0.408 & 560.3 & 30.0 & 33.4 & leaf & 8.398 \\
\hline 20 & $\mathrm{M}_{1.8} \mathrm{~T}_{0.8} \mathrm{Cr}_{0.2}$ & 0.328 & 0.407 & 559.7 & 29.2 & 46.6 & light yellow green & 8.420 \\
\hline 21 & $\mathrm{M}_{2} \mathrm{~T}$ & 0.311 & 0.315 & 511.0 & 0.7 & 81.7 & purplish white & 8.442 \\
\hline
\end{tabular}


Table 2. Spinel solid solutions in $\mathrm{CoO}-\mathrm{MgO}-\mathrm{Cr}_{2} \mathrm{O}_{3}-\mathrm{TiO}_{2}-\mathrm{SnO}_{2}$ system.

\begin{tabular}{|c|c|c|c|c|c|c|c|c|}
\hline No. & Composition & $x$ & $y$ & $\lambda_{D}(\mathrm{~m} \mu)$ & $P_{e}(\%)$ & $Y(\%)$ & Color & e constant $(\AA)$ \\
\hline 1 & $\mathrm{C}_{0.2} \mathrm{M}_{1.8} \mathrm{~S}$ & 0.200 & 0.204 & 477.2 & 53.0 & 25.1 & bright blue & 8.641 \\
\hline 2 & $\mathrm{C}_{0.2} \mathrm{M}_{1.6} \mathrm{~S}_{0.8} \mathrm{Cr}_{0.2}$ & 0.238 & 0.310 & 490.0 & 27.3 & 14.6 & dull blue green & 8.581 \\
\hline 3 & $\mathrm{C}_{0.2} \mathrm{M}_{1.8} \mathrm{~S}_{0.8} \mathrm{~T}_{0.2}$ & 0.212 & 0.235 & 480.2 & 44.7 & 25.5 & bright blue & 8.602 \\
\hline 4 & $\mathrm{C}_{0.2} \mathrm{M}_{1,4} \mathrm{~S}_{0.6} \mathrm{Cr}_{0.4}$ & 0.249 & 0.338 & 495.3 & 21.4 & 14.8 & dull bluish green & 8.512 \\
\hline 5 & $\mathrm{C}_{0.2} \mathrm{M}_{1,6} \mathrm{~S}_{0.6} \mathrm{~T}_{0.2} \mathrm{Cr}_{0.2}$ & 0.247 & 0.336 & 494.8 & 22.0 & 14.6 & dull bluish green & 8.538 \\
\hline 6 & $\mathrm{C}_{0.2} \mathrm{M}_{1.8} \mathrm{~S}_{0.6} \mathrm{~T}_{0.4}$ & 0.218 & 0.251 & 482.0 & 40.5 & 25.2 & bright blue & 8.567 \\
\hline 7 & $\mathrm{C}_{0.2} \mathrm{M}_{1.2} \mathrm{~S}_{0.4} \mathrm{Cr}_{0.6}$ & 0.253 & 0.348 & 497.8 & 19.3 & 16.7 & dull bluish green & 8.462 \\
\hline 8 & $\mathrm{C}_{0.2} \mathrm{M}_{1,4} \mathrm{~S}_{0.4} \mathrm{~T}_{0.2} \mathrm{Cr}_{0.4}$ & 0.260 & 0.368 & 540.0 & 16.4 & 14.0 & dull green & 8.473 \\
\hline 9 & $\mathrm{C}_{0.2} \mathrm{M}_{1.6} \mathrm{~S}_{0.4} \mathrm{~T}_{0.4} \mathrm{Cr}_{0.2}$ & 0.257 & 0.346 & 497.7 & 18.0 & 17.1 & dull bluish green & 8.498 \\
\hline 10 & $\mathrm{C}_{0.2} \mathrm{M}_{1.8} \mathrm{~S}_{0.4} \mathrm{~T}_{0.6}$ & 0.224 & 0.269 & 484.1 & 36.3 & 25.2 & bright greenish blue & 8.529 \\
\hline 11 & $\mathrm{C}_{0.2} \mathrm{M}_{1,0} \mathrm{~S}_{0.2} \mathrm{Cr}_{0.8}$ & 0.255 & 0.344 & 497.0 & 18.9 & 20.7 & dull bluish green & 8.380 \\
\hline 12 & $\mathrm{C}_{0.2} \mathrm{M}_{1,2} \mathrm{~S}_{0.2} \mathrm{~T}_{0.2} \mathrm{Cr}_{0.6}$ & 0.265 & 0.380 & 509.3 & 15.1 & 16.5 & strong green & 8.413 \\
\hline 13 & $\mathrm{C}_{0.2} \mathrm{M}_{1.4} \mathrm{~S}_{0.2} \mathrm{~T}_{0.4} \mathrm{Cr}_{0.4}$ & 0.269 & 0.378 & 510.5 & 14.0 & 15.8 & strong green & 8.437 \\
\hline 14 & $\mathrm{C}_{0.2} \mathrm{M}_{1.6} \mathrm{~S}_{0.2} \mathrm{~T}_{0.6} \mathrm{Cr}_{0.2}$ & 0.265 & 0.358 & 502.5 & 14.7 & 18.2 & dull green & 8.463 \\
\hline 15 & $\mathrm{C}_{0.2} \mathrm{M}_{1.8} \mathrm{~S}_{0.2} \mathrm{~T}_{0.8}$ & 0.228 & 0.288 & 486.7 & 33.0 & 24.8 & turquoise & 8.486 \\
\hline 16 & $\mathrm{C}_{0.2} \mathrm{M}_{0.8} \mathrm{Cr}$ & 0.236 & 0.325 & 492.3 & 26.9 & 22.3 & turquoise & 8.332 \\
\hline 17 & $\mathrm{C}_{0.2} \mathrm{M}_{1.0} \mathrm{~T}_{0.2} \mathrm{Cr}_{0.8}$ & 0.274 & 0.373 & 511.5 & 12.5 & 18.1 & dull green & 8.352 \\
\hline 18 & $\mathrm{C}_{0.2} \mathrm{M}_{1,2} \mathrm{~T}_{0.4} \mathrm{Cr}_{0,6}$ & 0.283 & 0.382 & 523.5 & 12.8 & 17.6 & dull green & 8.374 \\
\hline 19 & $\mathrm{C}_{0.2} \mathrm{M}_{1.4} \mathrm{~T}_{0.6} \mathrm{Cr}_{0.4}$ & 0.284 & 0.379 & 523.0 & 12.1 & 18.5 & dull green & 8.396 \\
\hline 20 & $\mathrm{C}_{0.2} \mathrm{M}_{1.6} \mathrm{~T}_{0.8} \mathrm{Cr}_{0.2}$ & 0.276 & 0.369 & 511.0 & 11.8 & 20.2 & dull green & 8.420 \\
\hline 21 & $\mathrm{C}_{0.2} \mathrm{M}_{1.8} \mathrm{~T}$ & 0.233 & 0.306 & 489.3 & 29.4 & 24.8 & turquoise & 8.443 \\
\hline \multicolumn{9}{|c|}{$(2)$} \\
\hline No. & Composition & $x$ & $y$ & $\lambda_{D}(\mathrm{~m} \mu)$ & $P_{e}(\%)$ & $Y(\%)$ & Color & Lattice constant $(\AA)$ \\
\hline 1 & $\mathrm{C}_{0.5} \mathrm{M}_{1.5} \mathrm{~S}$ & 0.191 & 0.190 & 476.5 & 58.0 & 14.8 & strong blue & 8.644 \\
\hline 2 & $\mathrm{C}_{0.5} \mathrm{M}_{1.3} \mathrm{~S}_{0.8} \mathrm{Cr}_{0.2}$ & 0.233 & 0.281 & 485.3 & 31.8 & 9.8 & dull greenish blue & 8.579 \\
\hline 3 & $\mathrm{C}_{0.5} \mathrm{M}_{1.5} \mathrm{~S}_{0.8} \mathrm{~T}_{0.2}$ & 0.210 & 0.240 & 481.2 & 44.7 & 15.2 & dull blue & 8.606 \\
\hline 4 & $\mathrm{C}_{0.5} \mathrm{M}_{1.1} \mathrm{~S}_{0.6} \mathrm{Cr}_{0.4}$ & 0.249 & 0.312 & 490.2 & 23.2 & 9.7 & dull blue green & 8.513 \\
\hline 5 & $\mathrm{C}_{0.5} \mathrm{M}_{1.3} \mathrm{~S}_{0.6} \mathrm{~T}_{0.2} \mathrm{Cr}_{0.2}$ & 0.235 & 0.315 & 490.8 & 28.0 & 13.3 & dull blue green & 8.541 \\
\hline 6 & $\mathrm{C}_{0.5} \mathrm{M}_{1.5} \mathrm{~S}_{0.6} \mathrm{~T}_{0.4}$ & 0.221 & 0.269 & 484.4 & 37.4 & 15.8 & dull greenish blue & 8.566 \\
\hline 7 & $\mathrm{C}_{0.5} \mathrm{M}_{0.9} \mathrm{~S}_{0.4} \mathrm{Cr}_{0.6}$ & 0.255 & 0.327 & 493.3 & 19.7 & 10.4 & dull blue green & 8.455 \\
\hline 8 & $\mathrm{C}_{0.5} \mathrm{M}_{1.1} \mathrm{~S}_{0.4} \mathrm{~T}_{0.2} \mathrm{Cr}_{0.4}$ & 0.252 & 0.347 & 497.4 & 19.7 & 12.4 & dull bluish green & 8.476 \\
\hline 9 & $\mathrm{C}_{0.5} \mathrm{M}_{1.3} \mathrm{~S}_{0.4} \mathrm{~T}_{0.4} \mathrm{Cr}_{0.2}$ & 0.249 & 0.340 & 495.7 & 21.1 & 12.7 & dull bluish green & 8.503 \\
\hline 10 & $\mathrm{C}_{0.5} \mathrm{M}_{1.5} \mathrm{~S}_{0.4} \mathrm{~T}_{0.6}$ & 0.232 & 0.295 & 487.6 & 30.8 & 15.6 & dull blue green & 8.528 \\
\hline 11 & $\mathrm{C}_{0.5} \mathrm{M}_{0.7} \mathrm{~S}_{0.2} \mathrm{Cr}_{0.8}$ & 0.254 & 0.334 & 494.8 & 19.7 & 12.9 & dull bluish green & 8.476 \\
\hline 12 & $\mathrm{C}_{0.5} \mathrm{M}_{0.9} \mathrm{~S}_{0.2} \mathrm{~T}_{0.2} \mathrm{Cr}_{0.6}$ & 0.261 & 0.366 & 503.8 & 16.0 & 12.2 & dull green & 8.412 \\
\hline 13 & $\mathrm{C}_{0.5} \mathrm{M}_{1.1} \mathrm{~S}_{0.2} \mathrm{~T}_{0.4} \mathrm{Cr}_{0.4}$ & 0.267 & 0.369 & 506.7 & 14.0 & 13.1 & dull green & 8.437 \\
\hline 14 & $\mathrm{C}_{0.5} \mathrm{M}_{1.3} \mathrm{~S}_{0.2} \mathrm{~T}_{0.6} \mathrm{Cr}_{0.2}$ & 0.262 & 0.366 & 504.0 & 15.7 & 15.1 & dull green & 8.460 \\
\hline 15 & $\mathrm{C}_{05}{ }_{5} \mathrm{M}_{1.5} \mathrm{~S}_{0.2} \mathrm{~T}_{0.8}$ & 0.242 & 0.320 & 491.6 & 25.0 & 17.9 & dull blue green & 8.487 \\
\hline 16 & $\mathrm{C}_{0.5} \mathrm{M}_{0.5} \mathrm{Cr}$ & 0.219 & 0.304 & 489.4 & 34.8 & 10.6 & strong blue green & 8.332 \\
\hline 17 & $\mathrm{C}_{0.5} \mathrm{M}_{0.7} \mathrm{~T}_{0.2} \mathrm{Cr}_{0.8}$ & 0.281 & 0.365 & 512.8 & 10.2 & 11.4 & dull green & 8.353 \\
\hline 18 & $\mathrm{C}_{0.5} \mathrm{M}_{0.9} \mathrm{~T}_{0.4} \mathrm{Cr}_{0.6}$ & 0.283 & 0.367 & 515.7 & 10.1 & 11.4 & dull green & 8.375 \\
\hline 19 & $\mathrm{C}_{0.5} \mathrm{M}_{1.1} \mathrm{~T}_{0.6} \mathrm{Cr}_{0.4}$ & 0.287 & 0.364 & 518.6 & 9.3 & 11.1 & dull green & 8.399 \\
\hline 20 & $\mathrm{C}_{0.5} \mathrm{M}_{1.3} \mathrm{~T}_{0.8} \mathrm{Cr}_{0.2}$ & 0.279 & 0.360 & 509.0 & 10.4 & 13.2 & dull green & 8.422 \\
\hline 21 & $\mathrm{C}_{0.5} \mathrm{M}_{1.5} \mathrm{~T}$ & 0.248 & 0.339 & 495.4 & 21.6 & 16.2 & dull bluish green & 8.445 \\
\hline \multicolumn{9}{|c|}{ (3) } \\
\hline No. & Composition & $x$ & $y$ & $\lambda_{D}(\mathrm{~m} \mu)$ & $P_{e}(\%)$ & $Y(\%)$ & \multicolumn{2}{|c|}{ Lattice constant $(\AA)$} \\
\hline 1 & CMS & 0.205 & 0.224 & 479.5 & 48.6 & 11.9 & strong blue & 8.651 \\
\hline 2 & $\mathrm{CM}_{0.8} \mathrm{~S}_{0.8} \mathrm{Cr}_{0.2}$ & 0.248 & 0.286 & 484.9 & 25.9 & 8.3 & dull greenish blue & 8.585 \\
\hline 3 & $\mathrm{CMS}_{0.8} \mathrm{~T}_{0.2}$ & 0.232 & 0.283 & 485.7 & 32.0 & 10.9 & dull greenish blue & 8.620 \\
\hline 4 & $\mathrm{CM}_{0.6} \mathrm{~S}_{0.6} \mathrm{Cr}_{0.4}$ & 0.276 & 0.314 & 489.5 & 13.0 & 7.1 & dark blue green & 8.518 \\
\hline 5 & $\mathrm{CM}_{0.8} \mathrm{~S}_{0.6} \mathrm{~T}_{0.2} \mathrm{Cr}_{0.2}$ & 0.277 & 0.330 & 496.0 & 11.4 & 7.8 & dull green & 8.544 \\
\hline 6 & $\mathrm{CMS}_{0.6} \mathrm{~T}_{0.4}$ & 0.255 & 0.324 & 492.6 & 20.0 & 9.7 & dull blue green & 8.578 \\
\hline 7 & $\mathrm{CM}_{0.4} \mathrm{~S}_{0.4} \mathrm{Cr}_{0.6}$ & 0.282 & 0.324 & 494.2 & 10.0 & 7.3 & dark grayish green & 8.450 \\
\hline 8 & $\mathrm{CM}_{0.6} \mathrm{~S}_{0.4} \mathrm{~T}_{0.2} \mathrm{Cr}_{0.4}$ & 0.294 & 0.335 & 506.0 & 5.3 & 7.2 & dark grayish green & 8.476 \\
\hline 9 & $\mathrm{CM}_{0.8} \mathrm{~S}_{0.4} \mathrm{~T}_{0.4} \mathrm{Cr}_{0.2}$ & 0.287 & 0.344 & 506.5 & 7.5 & 8.3 & grayish green & 8.503 \\
\hline 10 & $\mathrm{CMS}_{0.4} \mathrm{~T}_{0.6}$ & 0.266 & 0.342 & 493.0 & 15.8 & 11.0 & dull bluish green & 8.540 \\
\hline 11 & $\mathrm{CM}_{0.2} \mathrm{~S}_{0.2} \mathrm{Cr}_{0.8}$ & 0.279 & 0.334 & 497.9 & 10.5 & 8.1 & grayish green & 8.376 \\
\hline 12 & $\mathrm{CM}_{0.4} \mathrm{~S}_{0.2} \mathrm{~T}_{0.2} \mathrm{Cr}_{0.6}$ & 0.299 & 0.336 & 514.4 & 4.0 & 7.3 & dark grayish green & 8.410 \\
\hline 13 & $\mathrm{CM}_{0.6} \mathrm{~S}_{0.2} \mathrm{~T}_{0.4} \mathrm{Cr}_{0.4}$ & 0.300 & 0.344 & 527.2 & 5.5 & 7.9 & grayish green & 8.438 \\
\hline 14 & $\mathrm{CM}_{0.8} \mathrm{~S}_{0.2} \mathrm{~T}_{0.6} \mathrm{Cr}_{0.2}$ & 0.299 & 0.341 & 520.2 & 4.7 & 7.8 & grayish green & 8.468 \\
\hline 15 & $\mathrm{CMS}_{0.2} \mathrm{~T}_{0.8}$ & 0.278 & 0.361 & 509.0 & 10.8 & 11.7 & dull green & 8.498 \\
\hline 16 & $\mathrm{CCr}$ & 0.231 & 0.300 & 488.4 & 30.7 & 12.1 & dull blue green & 8.334 \\
\hline 17 & $\mathrm{CM}_{0.2} \mathrm{~T}_{0.2} \mathrm{Cr}_{0.8}$ & 0.302 & 0.323 & 501.5 & 2.7 & 7.2 & dark grayish green & 8.348 \\
\hline 18 & $\mathrm{CM}_{0.4} \mathrm{~T}_{0.4} \mathrm{Cr}_{0.6}$ & 0.307 & 0.335 & 541.4 & 4.3 & 7.4 & dark grayish green & 8.372 \\
\hline 19 & $\mathrm{CM}_{0.6} \mathrm{~T}_{0.8} \mathrm{Cr}_{0.4}$ & 0.307 & 0.342 & 544.0 & 6.2 & 8.2 & grayish green & 8.389 \\
\hline 20 & $\mathrm{CM}_{0.3} \mathrm{~T}_{0.8} \mathrm{Cr}_{0.2}$ & 0.305 & 0.358 & 544.4 & 10.1 & 9.1 & grayish green & 8.421 \\
\hline 21 & CMT & 0.292 & 0.375 & 530.1 & 12.0 & 11.8 & dull yellowish green & 8.453 \\
\hline
\end{tabular}


次の略記号を用いた.

$\mathrm{CoO}: \mathrm{C}, \mathrm{MgO}: \mathrm{M}, \mathrm{Cr}_{2} \mathrm{O}_{3}: \mathrm{Cr}, \mathrm{TiO}_{2}: \mathrm{T}, \mathrm{SnO}_{2}$ : S. よって, $0.5 \mathrm{CoO} 1.3 \mathrm{MgO} 0.6 \mathrm{SnO}_{2} 0.2 \mathrm{TiO}_{2} 0.2$ $\mathrm{Cr}_{2} \mathrm{O}_{3}$ は, $\mathrm{C}_{0.5} \mathrm{M}_{1.3} \mathrm{~S}_{0.6} \mathrm{~T}_{0.2} \mathrm{Cr}_{0.2}$ と表示できる.

\section{4. 考察と結論}

\section{$4.1 \mathrm{MgO}-\mathrm{Cr}_{2} \mathrm{O}_{3}-\mathrm{TiO}_{2}-\mathrm{SnO}_{2}$ 系}

表-1 に示した試料は全部単一スピネルであり，スピ ネル混合物ではない，試料の組成と格子定数との関係を 図-2 に示す. 図中の番号は, 図-1 の同じ番号に対応す る. 以下，図一住した組成三角形に捣いて，まず 3 つの各辺の組成の試料につき, 次に内部の組成の試料に つき検討と考察を加える.

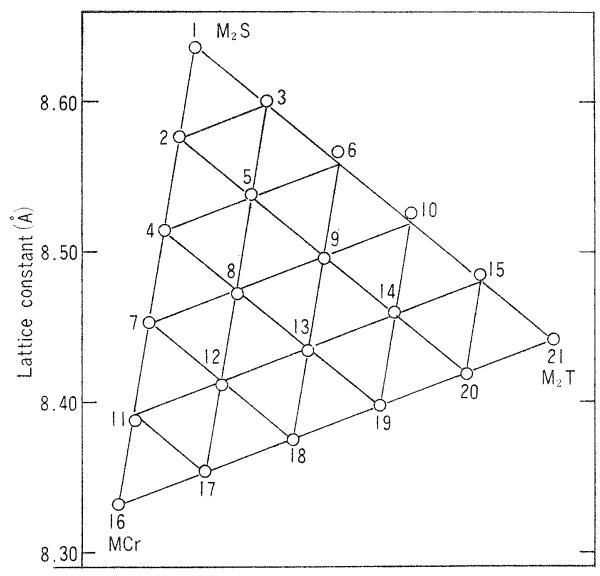

Fig. 2. Lattice constant of spinels in $\mathrm{MgO}-\mathrm{Cr}_{2} \mathrm{O}_{3}-$ $\mathrm{TiO}_{2}-\mathrm{SnO}_{2}$ system.

4.1 .1 陽イオン分布 $\mathrm{MgO}-\mathrm{Cr}_{2} \mathrm{O}_{3}-\mathrm{TiO}_{2}-\mathrm{SnO}_{2}$ 系 スピネル固溶体中の陽イオン分布は次のようである. $\mathrm{Mg}^{2+}$ はそれほど強い配位選択性はなく，いずれかとい えば 6 配位選択性をもつが9 ， スピネルでは 4 配位の位 置にも入る ${ }^{109}$. $\mathrm{Ti}^{4+}, \mathrm{Sn}^{4+}$ は 6 配位の位置に入り, $\mathrm{Cr}^{3+}$

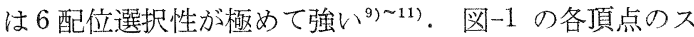
ピネルでは，その陽イオン分布は，スピネル6配位の位 置を［］で囲むと，それぞれ $\mathrm{Mg}[\mathrm{MgSn}] \mathrm{O}_{4}, \mathrm{Mg}\left[\mathrm{Cr}_{2}\right]$ $\mathrm{O}_{4}, \mathrm{Mg}[\mathrm{MgTi}] \mathrm{O}_{4}$ となり，錫およびチタンスピネルで， $\mathrm{Mg}^{2+}$ は 4, 6 各配位の位置に入っている.よって，こ の3つのスピネル間固溶体では, $\mathrm{Cr}^{3+}, \mathrm{Ti}^{4+}, \mathrm{Sn}^{4+}$ はつ 衫 6 配位， $\mathrm{Mg}^{2+}$ は 4 配位と 6 配位の位置に入ること が推察される。

4.1.2 $\mathrm{MgO}-\mathrm{Cr}_{2} \mathrm{O}_{3}-\mathrm{SnO}_{2}$ 系 (1) 図-1の No. 1-2-4-7-11-16 がこの系で，図-2 に示すように，格子 定数はVegard 則に従い，両端スピネル間を置換量に 空じ, 直線的に変化している。この理由の1つとして, No. 1 の $\mathrm{Mg}[\mathrm{MgSn}] \mathrm{O}_{4}$ に $\mathrm{Mg}^{2+}+\mathrm{Sn}^{4+} \rightleftarrows 2 \mathrm{Cr}^{3+}$ の 置換をした試料の陽イオン分布は, $\mathrm{Mg}\left[\mathrm{Mg}_{(1-x)} \mathrm{Sn}_{(1-x)}\right.$

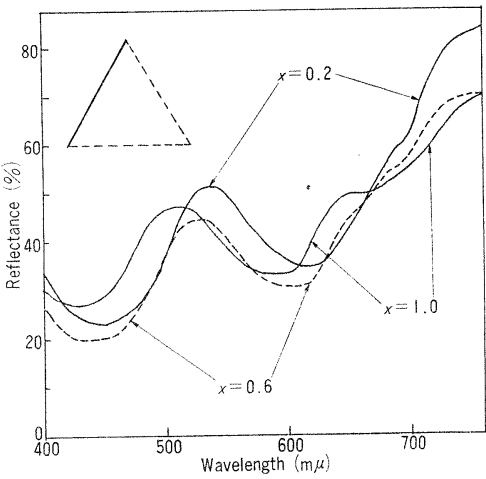

Fig. 3. Reflectance spectra of $(2-x) \mathrm{MgO}(1-x)$ $\mathrm{SnO}_{2} x \mathrm{Cr}_{2} \mathrm{O}_{3}$.

$\left.\mathrm{Cr}_{2 x}\right] \mathrm{O}_{4}$ で，置換は 6 配位の位置のみで行なわれてお り，格子定数に及ぼす影響は，常に一定であることが考 えられる。

（2）図-3 にこの系の分光反射率曲線を示す.

$(2-x) \mathrm{MgO}(1-x) \mathrm{SnO}_{2} x \mathrm{Cr}_{2} \mathrm{O}_{3}$ で, $x=0.2$ では, 440〜450，620 m $\mu$ に吸収があり，これは $\mathrm{Cr}^{3+}$ のもの である. 反射は約 $535 \mathrm{~m} \mu$ にあり， $x$ すなおち $\mathrm{Cr}^{3+}$ が

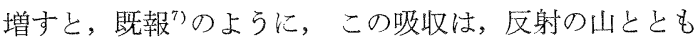
に紫側に移動する。この理由は，両端スピネル $2 \mathrm{MgO}$ $\mathrm{SnO}_{2}, \mathrm{MgOCr}_{2} \mathrm{O}_{3}$ において, 6 配位の位置での陽イオ ン一酸素イオン間距離が，それぞれ $2.12 ， 2.00 \AA$ とな $り^{12)}$ ，クロムスピネル側で小となるためと考えられる. $x=1$ の $\mathrm{MgOCr}_{2} \mathrm{O}_{3}$ では, $430,590 \mathrm{~m} \mu$ に吸収, 約 510 $\mathrm{m} \mu$ に反射があるが，これらの位置は文献值 ${ }^{13)}$ と大体一 致する。色調は表-1 に示すように，黄緑から死緑にか け変化する。

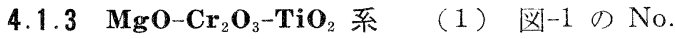
16-17-18-19-20-21 がこの系で, その組成は $(2-x)$ $\mathrm{MgO}(1-x) \mathrm{TiO}_{2} x \mathrm{Cr}_{2} \mathrm{O}_{3}$ である. その格子定数は, 図一 2 に示すように, 雨端のスピネル間を置換量に応じ, 大 体直線的に変化している。この系も 4.1 .2 項の系と同 様, $\mathrm{Mg}^{2+}+\mathrm{Ti}^{4+} \rightleftarrows 2 \mathrm{Cr}^{3+}$ の置換が 6 配位の位置の夕で おきるため，格子定数の変化が直線的となると考元られ る.

（2）この系の分光反射率曲線を図-4 に示す.

$(2-x) \mathrm{MgO}(1-x) \mathrm{TiO}_{2} x \mathrm{Cr}_{2} \mathrm{O}_{3}$ で $x=0$ を除き, $\mathrm{Cr}^{3+}$ の吸収があり， $x=0.2$ では， $620 \mathrm{~m} \mu$ を中心とする吸 収のほか，紫外部からかなり強い吸収が可視部にくい込 み，反射の山は $530 \sim 535 \mathrm{~m} \mu$ にある。これらの吸収と 反射は, $\mathrm{Cr}^{3+}$ の増すにつれ，次第に紫側に移動し， $x=$ 1.0 の No. 16 では，4.1.2 項に示した位置となる. スピネル 6 配位の位置における陽イオン一酸素イオン間 距離は, 夕ロムスピネルで $2.00 \AA$ ，千多ンスピネルで $2.01 \AA$ と報告され ${ }^{12)}$ ，ほとんど差がないようであるが， $\mathrm{Cr}^{3+}$ の吸収は紫側に移動し，その移動の幅は，4.1.2 項 


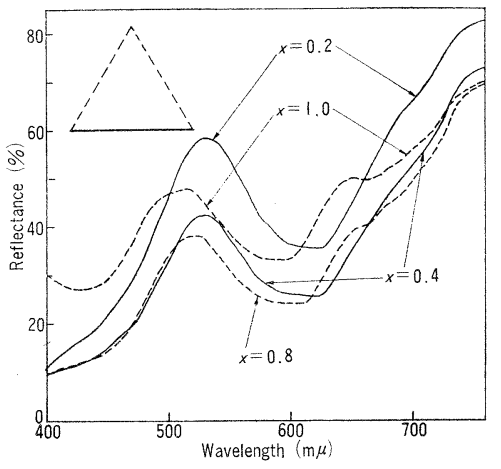

Fig. 4. Reflectance spectra of $(2-x) \mathrm{MgO}(1-x)$ $\mathrm{TiO}_{2} x \mathrm{Cr}_{2} \mathrm{O}_{3}$.

の $(2-x) \mathrm{MgO}(1-x) \mathrm{SnO}_{2} x \mathrm{Cr}_{2} \mathrm{O}_{3}$ の場合とほぼ等し い. 色調は No. 21 の白を除き, 黄緑から No. 16 の灰 緑にかけ変化する.

4.1.4 $\mathrm{MgO}-\mathrm{TiO}_{2}-\mathrm{SnO}_{2}$ 系 図-1 の No. 1-3-610-15-21 の系で, 組成は $2 \mathrm{MgO}(1-x) \mathrm{SnO}_{2} x \mathrm{TiO}_{2}$ で ある.4.1.2, 4.1.3 項同様, 格子定数は両端スピネル間 を置換量に応じ，直線的に変化している．この系は $\mathrm{Cr}^{3+}$ を含まない。

\subsection{5 $\mathrm{MgO}-\mathrm{Cr}_{2} \mathrm{O}_{3}-\mathrm{TiO}_{2}-\mathrm{SnO}_{2}$ 系 (1) $\mathrm{Ti}^{4+}$ を} 一定にし, $\mathrm{Mg}^{2+}+\mathrm{Sn}^{4+} \rightleftarrows 2 \mathrm{Cr}^{3+}$ の置換をした系

表-1, 図-1 の 3-5-8-12-17 の系で，その組成は (2$x) \mathrm{MgO} 0.2 \mathrm{TiO}_{2}(0.8-x) \mathrm{SnO}_{2} x \mathrm{Cr}_{2} \mathrm{O}_{3}$ である。この系 と平行する 6-9-13-18，10-14-19 の系も，格子定数の 変化は図-2に示すように, 各両端スピネル間を置換量 に応じ，直線的に変化している. 図 -5 に分光反射率曲 線を示す. 上記組成で, $x=0.2$ の No. 5 では 430 $435,620 \mathrm{~m} \mu$ に吸収， $535 \mathrm{~m} \mu$ に反射があるが， $\mathrm{Cr}^{3+}$ が 増すと, 短波長側の $\mathrm{Cr}^{3+}$ の吸収は, 紫外部にかけての 深い谷となり, その移動は追跡し難いが, 長波長側の吸 収が紫側へ移動するのはみとめられ，この点，No. 1〜 16 の系と同様の傾向である. 色調も $\mathrm{Cr}^{3+}$ が増すと, 表-1 に示すよ5に, やや灰緑をおびる.

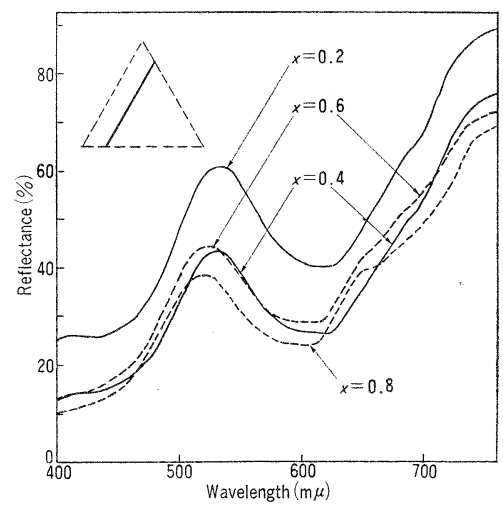

Fig. 5. Reflectance spectra of $(2-x) \mathrm{MgO} 0.2 \mathrm{TiO}_{2}$ $(0.8-x) \mathrm{SnO}_{2} x \mathrm{Cr}_{2} \mathrm{O}_{3}$.
(2) $\mathrm{Sn}^{4+}$ を一定にして, $\mathrm{Mg}^{2+}+\mathrm{Ti}^{4+} \rightleftarrows 2 \mathrm{Cr}^{3+}$ の 置換をした系

表-1, 図-1 の 11-12-13-14-15 で, その組成が (2$x) \mathrm{MgO} 0.2 \mathrm{SnO}_{2}(0.8-x) \mathrm{TiO}_{2} x \mathrm{Cr}_{2} \mathrm{O}_{3}$ の系では, これ と平行の 7-8-9-10，4-5-6 の系と同様, 格子定数は図2 に示すよ5に, 各両端スピネル間を置換量に応じ,直線 的に変化している. 分光反射率曲線索図-6に示す. $x=$ 0 の No. 15 には $\mathrm{Cr}^{3+}$ の吸収はないが， $x=0.2$ の No. 14 で 620 625 m $\mu$ にあった吸収は, $535 \mathrm{~m} \mu$ の反射と ともに, $\mathrm{Cr}^{3+}$ の増加にともない紫側に移動し， $x=0.8$ の No. 11 では $600 \mathrm{~m} \mu$ にあり,さらに $435 \mathrm{~m} \mu$ にも 吸収が夕とめられ，反射は $520 \mathrm{~m} \mu$ にある。他の系同 様, $\mathrm{Cr}^{3+}$ が増すと, やや灰味の緑となる.

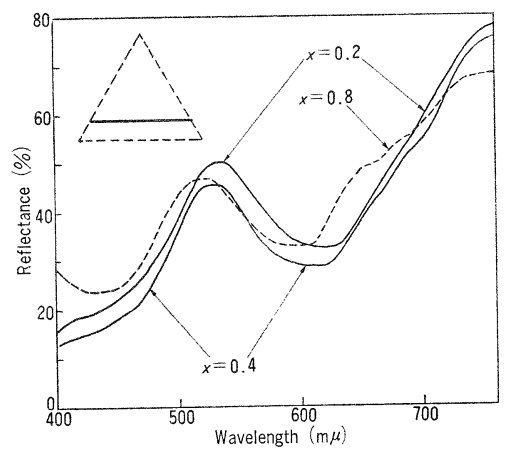

Fig. 6. Reflectance spectra of $(2-x) \mathrm{MgO}$ $0.2 \mathrm{SnO}_{2}(0.8-x) \mathrm{TiO}_{2} x \mathrm{Cr}_{2} \mathrm{O}_{3}$.

（3） $\mathrm{Cr}^{3+}$ を一定にして, $\mathrm{Sn}^{4+} \rightleftarrows \mathrm{Ti}^{4+}$ の置換をし た系

表-1, 図-1 の No. 2-5-9-14-20 の $1.8 \mathrm{MgO} 0.2$ $\mathrm{Cr}_{2} \mathrm{O}_{3}(0.8-x) \mathrm{SnO}_{2} x \mathrm{TiO}_{2}$ の系で, これと平行の 4-813-19，7-12-18 の系も図-2 に示すように, 格子定数の 変化は，(1), (2) と同様直線的である. $x=0$ の No. 2 から $x=0.8$ の No. 20 にかけ, $\mathrm{Sn}^{4+}$ の増加により格 子定数は大となるが，吸収および反射は大体 $620 \mathrm{~m} \mu$ と $535 \mathrm{~m} \mu$ にあり, 図-7 でみられるよらに, それほど移動

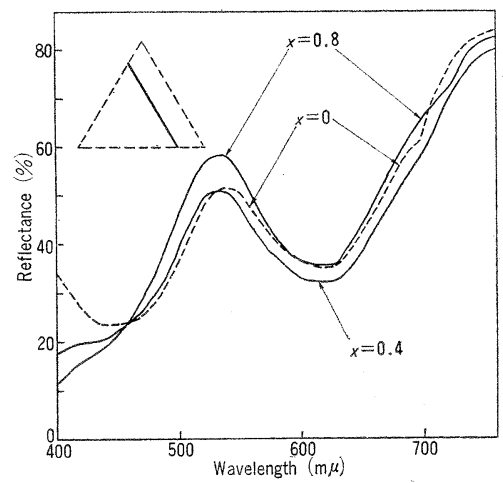

Fig. 7. Reflectance spectra of $1.8 \mathrm{MgO}$ $0.2 \mathrm{Cr}_{2} \mathrm{O}_{3}(0.8-x) \mathrm{SnO}_{2} x \mathrm{TiO}_{2}$. 
はみとめられない。このほか $x=0$ では, さらに 440〜 $450 \mathrm{~m} \mu$ に吸収がある。 $\mathrm{Cr}^{3+}$ の吸収が他の系と異なり， 移動を示さぬ理由は, 検討を要する。これと同様の現象 は，No.4-8-13-19 の系にもみられる.

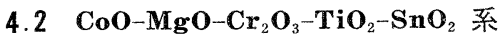

この系は, 表-2(1)〜 (3) に示すよらに, $2 \mathrm{MgOSnO}_{2}$ 打よび $2 \mathrm{MgOTiO}_{2}$ の $\mathrm{Mg}^{2+}$ を，それぞれ $10,25,50 \%$ $\mathrm{Co}^{2+}$ で置換したスピネル, $0.2 \mathrm{CoO} 1.8 \mathrm{MgOSnO}_{2}, 0.5$ $\mathrm{CoO} 1.5 \mathrm{MgOSnO}_{2}, \mathrm{CoOMgOSnO}_{2}$ および $0.2 \mathrm{CoO}$ $1.8 \mathrm{MgOTiO}_{2}, 0.5 \mathrm{CoO} 1.5 \mathrm{MgOTiO}_{2}, \mathrm{CoOMgOTiO}_{2}$ につき, 錫スピネルで $\mathrm{Mg}^{2+}+\mathrm{Sn}^{4+} \rightleftarrows 2 \mathrm{Cr}^{3+}$, チタンス ピネルで $\mathrm{Mg}^{2+}+\mathrm{Ti}^{4+} \rightleftarrows 2 \mathrm{Cr}^{3+}$ の置換を各 $100 \%$ したと き誘導されるクロムスピネル $0.2 \mathrm{CoO} 0.8 \mathrm{MgOCr}_{2} \mathrm{O}_{3}$, $0.5 \mathrm{CoO} 0.5 \mathrm{MgOCr}_{2} \mathrm{O}_{3}$ および $\mathrm{CoOCr}_{2} \mathrm{O}_{3}$ をそれぞれ 組成三角形の頂点におき, 4.1 項と同様, 各三角形につ き，21 個の試料を調製し，検討した。いずれも表-2(1) 〜 (3) に示すように, 単一スピネルを生成している. その組成と格子定数との関係を $\mathrm{Mg}^{2+}$ を $10 \% \mathrm{Co}^{2+}$ で置 換した系につき, 図-8 に示す。この図でみられる組成 に対する格子定数の变化の様子は，他の $25 \%$ および 50 $\%$ 置換の系と同様である.

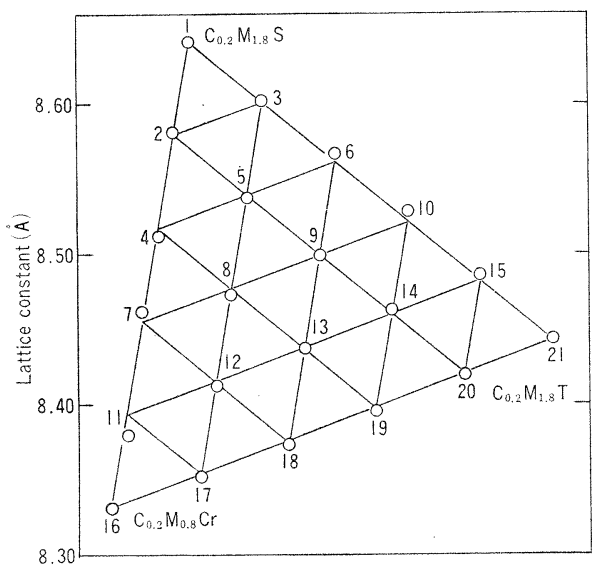

Fig. 8. Lattice constant of spinels in $\mathrm{CoO}-$ $\mathrm{MgO}-\mathrm{Cr}_{2} \mathrm{O}_{3}-\mathrm{TiO}_{2}-\mathrm{SnO}_{2}$ system.

4.2 .1 陽イオン分布 $\mathrm{Co}^{2+}$ は余り強くないが， 4 配位選択性をも ${ }^{10), 11)}, x \mathrm{CoO}(1-x) \mathrm{MgOCr}_{2} \mathrm{O}_{3}$ では, $\mathrm{Co}_{x} \mathrm{Mg}_{(1-x)}\left[\mathrm{Cr}_{2}\right] \mathrm{O}_{4}$ の陽イオン分布でつねに 4 配位の 位置に大る. $x \mathrm{CoO}(2-x) \mathrm{MgOTiO}_{2}$ では, 大体 $x=1$ の組成付近まで 4 配位の位置に入り， $x>1$ では当然 6 配位の位置にも入るようになる. 一方, $x \mathrm{CoO}(2-x)$ $\mathrm{MgOSnO}_{2}$ では, DuMont ${ }^{14)}$ の指摘するように, $\mathrm{Co}^{2+}$ は両方の位置に同時に入るとされており，既報 ${ }^{3}$ のよら に, $x=1$ の組成では, 6 配位 $\mathrm{Co}^{2+}$ の吸収が, 紫〜緑 の部分にあらわれている. しかし， $x=0.2 \sim 0.5$ の組成 では, 吸収曲線の形状から 6 配位 $\mathrm{Co}^{2+}$ の量は少ないと
推定される.よって， $\mathrm{Co}^{2+}$ は一部その含量の多い組成 の錫スピネル側で，6配位の位置にも入ることが考えら

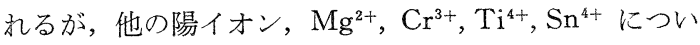
ては, 4.1 項の場合と同様と推定される. 組成の変化に よる吸収曲線の形状の変化は，いずれも同じ傾向を示す ため, 以下，表-2(1) の $10 \% \mathrm{Co}^{2+}$ を置換した系につ き図示する。

4.2.2 $\mathrm{CoO}-\mathrm{MgO}-\mathrm{Cr}_{2} \mathrm{O}_{3}-\mathrm{SnO}_{2}$ 系 (1) 図-1の No. 1-2-4-7-11-16 の系で, 図-8 から, 格子定数は両 端スピネル間を置換量に応じ，大体直線的に変化してい る.この系, すなわち, $0.2 \mathrm{CoO}(1.8-x) \mathrm{MgO}(1-x)$ $\mathrm{SnO}_{2} x \mathrm{Cr}_{2} \mathrm{O}_{3}$ 系スピネルの分光反射率曲線を四 -9 に示 す. $x=0$ の $0.2 \mathrm{CoO} 1.8 \mathrm{MgOSnO}_{2}$ には, 495 500, $565,605 \sim 610,660 \sim 670 \mathrm{~m} \mu$ に吸収があり, 後の $3 つ$ が強く，緑から赤の部分に梁い吸収をつくっている。こ れらはいずれも 4 配位 $\mathrm{Co}^{2+}$ のもので, 紫〜青の部分の 強い反射とともに，鮮明な青の発色を示す。いわゆるセ ルリアンの標準色は, $0.2 \mathrm{CoO} 1.8 \mathrm{MgOSnO}_{2} \sim 0.5 \mathrm{CoO}$ $1.5 \mathrm{MgOSnO}_{2}$ のスピネルが示すものである。上記 $\mathrm{Co}^{2+}$ の吸収は，位置は多少ずれるが，4配位 $\mathrm{Co}^{2+}$ を含む他 の顔料 ${ }^{22,6), 15)}$ に同様のものがみられる。

(2) $x=1$ の $0.2 \mathrm{CoO} 0.8 \mathrm{MgOCr}_{2} \mathrm{O}_{3}$ には, $430 \sim$ $435,570,610 \sim 615,660 \sim 670 \mathrm{~m} \mu$ に吸収があり,さら にやや不鮮明ではあるが，490 495 m る.これは 430〜 435 m $\mu$ の吸収をのぞく他の 3 つとと もに, やはり 4 配位. $\mathrm{Co}^{2+}$ のもので, 既報吕のように, 両端の錫およびクロムスピネルにおいて，4配位の位置 での陽イオン一酸素イオン間距離がともに $1.95 \AA$ であ り，このため, ほとんど $\mathrm{Co}^{2+}$ の吸収の移動がみとめら

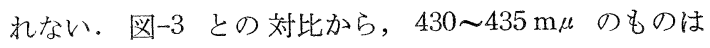
$\mathrm{Cr}^{3+}$ の吸收で，他の 1 つの $\mathrm{Cr}^{3+}$ の吸収は大体 $590 \mathrm{~m} \mu$ 付近にあるが, これは 4 配位 $\mathrm{Co}^{2+}$ の吸収と重複し, 判 別し難い。この系では, 結局, $\mathrm{Co}^{2+}$ の吸収はほとんど 移動せず， $\mathrm{Cr}^{3+}$ の吸収がその増加するにつれ，次第に 強くなりながら紫側に移動する。

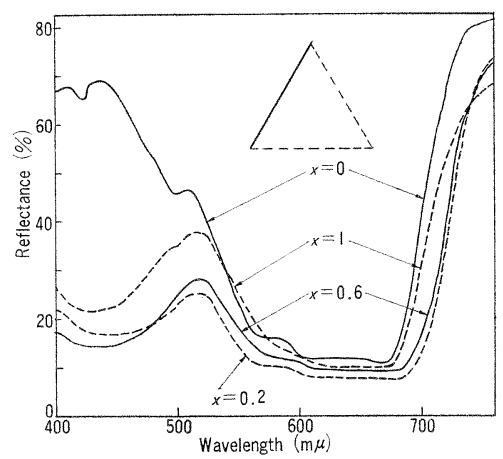

Fig. 9. Reflectance spectra of $0.2 \mathrm{CoO}(1.8-x)$ $\mathrm{MgO}(1-x) \mathrm{SnO}_{2} x \mathrm{Cr}_{2} \mathrm{O}_{3}$. 
(3) $0.2 \mathrm{CoO}(1.8-x) \mathrm{MgO}(1-x) \mathrm{SnO}_{2} x \mathrm{Cr}_{2} \mathrm{O}_{3}$ で $\mathrm{Cr}^{3+}$ が人ると，そのため，特に500 $\mathrm{m} \mu$ より短波長側 の吸収が大となり， $x=0.2$ で大体， $450 \mathrm{~m} \mu$ を底とす る吸収となり， $x$ の増すにつれ，次第に紫側に移動す る.この部分の谷は， $x=0.4 \sim 0.6$ で最も深くなり, こ れと相まって，緑から赤にかけての深い谷でも，約 680 $\mathrm{m} \mu$ より長波長側の吸収が 1 度強くなり, 色調は 1 番緑 による. 表-2(1) に示すように, 主波長もこの付近で 1 番長くなり,さらに, $\mathrm{Cr}^{3+}$ が増すと, $\mathrm{CoO}-\mathrm{MgO}-\mathrm{Cr}_{2} \mathrm{O}_{3}$ 系スピネルの青味の強い緑となり，主波長は再び短くな る。

\subsection{3 $\mathrm{CoO}-\mathrm{MgO}-\mathrm{Cr}_{2} \mathrm{O}_{3}-\mathrm{TiO}_{2}$ 系 (1) 図-1の} No. 16-17-18-19-20-21 の系で, $0.2 \mathrm{CoO}(1.8-x)$ $\mathrm{MgO}(1-x) \mathrm{TiO}_{2} x \mathrm{Cr}_{2} \mathrm{O}_{3}$ の組成である。図-8 に示すよ らに，4.2.2 項同様, 格子定数の変化は直線的である。 $x=0$ の No. 21, 0.2 CoO 1.8 $\mathrm{MgOTiO}_{2}$ には, 図-10 から 4 配位 $\mathrm{Co}^{2+}$ の吸収が 505 510，590，620，680〜 $690 \mathrm{~m} \mu$ にある他，青から紫外部にかけ強い吸収がある が,この吸収は, DuMont ら ${ }^{16)}$ の指摘するように, $\mathrm{Co}^{2+}$ 〜 $\mathrm{Ti}^{4+}$ 間の相互作用によるものである. これらの吸収 のうち，505〜 510 m $\mu$ のもを除く各吸収は，いずれも 強く, 紫外線から可視部にかけてと, 緑から赤の部分と を大きくカットし，色調を青緑によせている。

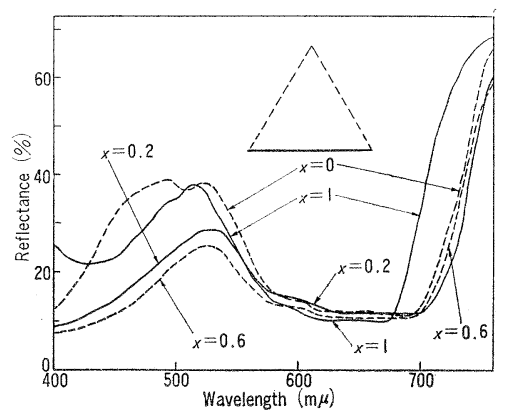

Fig. 10. Reflectance spectra of $0.2 \mathrm{CoO}$. $(1.8-x) \mathrm{MgO}(1-x) \mathrm{TiO}_{2} x \mathrm{Cr}_{2} \mathrm{O}_{3}$.

(2) 上記の組成で $\mathrm{Cr}^{3+}$ が入ると, 約 $400 \sim 500 \mathrm{~m} \mu$ の紫から青緑の部分での吸収が大となり, 同時に緑から 赤にわたる吸収の赤側での立上りが，さらに長波長側に 移動し, 吸収の谷の幅が広くなる. 紫〜青緑の部分の吸 収は， $x=0.4 \sim 0.6$ で最も深くなり，表-2(1) でみられ るように, 中間の組成で主波長は 1 番長くなる。両端ス ピネルの色名は, ターコイスという青緑であるが, 中間 で緑になる。この系では, $\mathrm{Co}^{2+}, \mathrm{Cr}^{3+}$ はともに配位数 は変化せず, かつ $\mathrm{Cr}^{3+}$ の吸収は, $\mathrm{CoO}-\mathrm{MgO}-\mathrm{TiO}_{2}$ 系 スピネルの吸収と重複してあらわれるため, 置換による 色の変化は, 4.2 .2 項に比し少である.

$x=0$ の No. 16 は, 4.2.2 項で示した位置に $\mathrm{Co}^{2+}$, $\mathrm{Cr}^{3+}$ の吸収があり, クロムスピネル側で各吸収とも紫
側によるが， $\mathrm{Co}^{2+}$ の吸収が移動する理由は，4配位の 位置での陽イオン一酸素イオン間距離が，チタンスピネ ルで, $2.00 \AA$ クロムスピネルで $1.95 \AA$ で, クロムス ピネル側で短いためである. $\mathrm{Cr}^{3+}$ の吸収の移動につい

ては, 4.1.2〜4.1.5 項で論じた.

4.2.4 $\mathrm{CoO}-\mathrm{MgO}^{-} \mathrm{TiO}_{2}-\mathrm{SnO}_{2}$ 系园-1 $の \mathrm{No}$ 1-3-6-10-15-21 の系で, 組成は $0.2 \mathrm{CoO} 1.8 \mathrm{MgO}$ $(1-x) \mathrm{TiO}_{2} x \mathrm{SnO}_{2}$, その格子定数は図-8 に示すように, 他の系同様,直線的に変化している。4.2.2 項および4.2. 3 項で検討した錫スピネルおよびチタンスピネルでの 4 配位 $\mathrm{Co}^{2+}$ の吸収は, 錫スピネル側で，格子定数が大で あるにもかかわらず，チタンスピネルのそれより紫側に よっている.この理由は, Reinen ら ${ }^{12)}$, DuMont $5^{16}$ の指摘するように，錫スピネル側で，4配位の位置での 陽イオン一酸素イオン間距離が $1.95 \AA$ で,これがチ夕 ンスピネルのそれの $2.00 \AA$ より短いためである。図 11 に,この系の分光反射率曲線を示す。上の組成で $\mathrm{Ti}^{4+}$ が増すと, $\mathrm{Co}^{2+}$ の吸収が赤側に移動するのがみとめら れ，色調は表-2(1) に示すように，七ルリアンの青から 青緑に変化する。

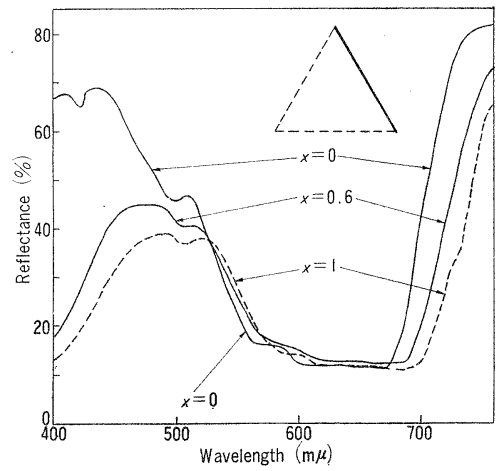

Fig. 11. Reflectance spectra of $0.2 \mathrm{CoO} 1.8$ $\mathrm{MgO}(1-x) \mathrm{SnO}_{2} x \mathrm{TiO}_{2}$.

\subsection{5 $\mathrm{CoO}-\mathrm{MgO}_{-}-\mathrm{Cr}_{2} \mathrm{O}_{3}-\mathrm{TiO}_{2}-\mathrm{SnO}_{2}$ 系}

(1) $\mathrm{Ti}^{4+}$ を一定にして, $\mathrm{Mg}^{9+}+\mathrm{Sn}^{4+} \rightleftarrows 2 \mathrm{Cr}^{3+}$ の置 換をした系

図-1 の No. 3-5-8-12-17 で, $0.2 \mathrm{CoO}(1.8-x)$ $\mathrm{MgO} 0.2 \mathrm{TiO}_{2}(0.8-x) \mathrm{SnO}_{2} x \mathrm{Cr}_{2} \mathrm{O}_{3}$ の組成をもつ. 困 -8 から, 格子定数は他の系同様, 両端スピネル間を置 換量に応じ，大体直線的に変化している. 上式で $\mathrm{Cr}^{3+}$ が入ると, 図-12 に示すように, 約 $400 \sim 520 \mathrm{~m} \mu$ まで の短波長側が， $\mathrm{Cr}^{3+}$ のため大きくカットされ，No. 3 の青が緑による. $\mathrm{Cr}^{3+}$ の吸収の位置は図 -5 との対比か ら推定できる． $x=0$ で 505 510, 570,610, $670 \mathrm{~m} \mu$ に 4 配位 $\mathrm{Co}^{2+}$ の吸収があり,この吸収はほとんど移動し ない.ただ, 分光反射曲線は $x=0.4$ 位で, とくに 400 $\sim 520 \mathrm{~m} \mu$ までの吸收が深くなり, 以後, 可視部全域で 幾分反射が大となる。よって, 三角形の内部で主波長は 


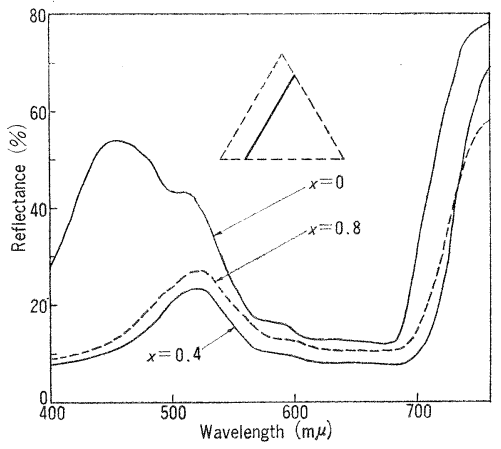

Fig. 12. Reflectance spectra of $0.2 \mathrm{CoO}(1.8-x)$ $\mathrm{MgO} 0.2 \mathrm{TiO}_{2}(0.8-x) \mathrm{SnO}_{2} x \mathrm{Cr}_{2} \mathrm{O}_{3}$

最大となる. $x=0.8$ の No. 17 では, 約 $520 \mathrm{~m} \mu$ を中 心とする反射の両側に深い吸収があり，緑色を示す。こ れと平行の No. 6-9-13-18，10-14-19 でも，置換によ る色調に変化は，この系と同じ傾向を示す.

(2) $\mathrm{Sn}^{4+}$ を一定にして, $\mathrm{Mg}^{2+}+\mathrm{Ti}^{4+} \rightleftarrows 2 \mathrm{Cr}^{3+}$ の 置換をした系

図-1 の No. 11-12-13-14-15 の $0.2 \mathrm{CoO}(1.8-x)$ $\mathrm{MgO} 0.2 \mathrm{SnO}_{2}(0.8-x) \mathrm{TiO}_{2} x \mathrm{Cr}_{2} \mathrm{O}_{3}$ の組成をもつ系で, 格子定数は他の系と同様, 直線的に変化している。図一 13 にこの系の分光反射率曲線を示す. $\mathrm{Cr}^{3+}$ の吸収は, 図-6 との対比から，その位置を推定できる. $\mathrm{Cr}^{3+}$ が入 ると，その影響はやはり紫〜青の部分でとくに強くあら われ，そのため $\mathrm{Cr}^{3+}$ を含まない No. 15 の青緑は大き く緑による.この系でも, 中間の組成で, 吸収曲線の 400 520 m $\mu$ 付近までが吸収が強くなるため，No. 13 付近で主波長が 1 度長くなり, 再び No. 11 で青味をお びた緑となる. $x=0$ の No. 15 で, 510, 590, 620, 685 $\mathrm{m} \mu$ にある 4 配位 $\mathrm{Co}^{2+}$ の吸収は, $x=0.8$ の No. 11 では，最初の $510 \mathrm{~m} \mu$ に相当するものは不鮮明である が，大体 $500 \mathrm{~m} \mu$ にあり，他はそれぞれ 570～580, 610， $670 \mathrm{~m} \mu$ にあり, いずれも紫側に移動している. (1) と 同様， $\mathrm{Cr}^{3+}$ の吸収の 1 つは $435 \mathrm{~m} \mu$ にあるが，他は $\mathrm{Co}^{2+}$ のそれと重複し, 判別し難い。

(3) $\mathrm{Cr}^{3+}$ を一定にし, $\mathrm{Sn}^{4+} \rightleftarrows \mathrm{Ti}^{4+}$ の置換をした系

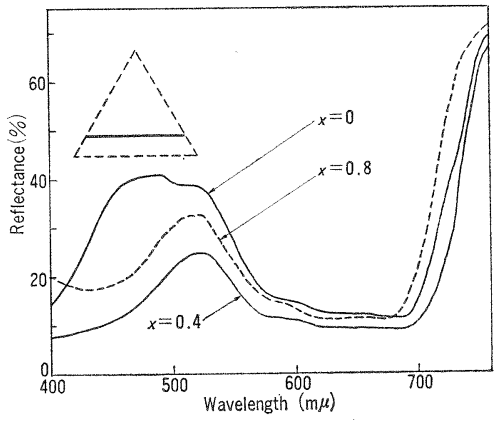

Fig. 13. Reflectance spectra of $0.2 \mathrm{CoO}(1.8-x)$ $\mathrm{MgO} 0.2 \mathrm{SnO}_{2}(0.8-x) \mathrm{TiO}_{2} x \mathrm{Cr}_{2} \mathrm{O}_{3}$.
図-1 の No. 2-5-9-14-20 の系で，格子定数の置換に よる変化は，図-8 より，直線的である。この系は 0.2 $\mathrm{CoO} 1.6 \mathrm{MgO} 0.2 \mathrm{Cr}_{2} \mathrm{O}_{3}(0.8-x) \mathrm{SnO}_{2} x \mathrm{TiO}_{2}$ の組成で, $x=0$ の No. 2 には, 図-14 から，445, 565, 610, 660 〜 685 m に吸收があり，445 $\mathrm{m} \mu$ のものは図-7 との対

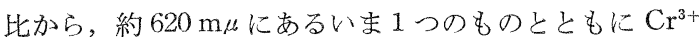
の吸収であることがわかるただし，後者は $\mathrm{Co}^{2+}$ の吸 収と重複し, 判別し難い。この他の吸収は, 4 配位 $\mathrm{Co}^{2+}$ のもので，各吸収は $\mathrm{Ti}^{4+}$ が増すと赤側に移動し， $x=$ 0.8 では，590，620，680 m/にあり， $\mathrm{Cr}^{3+}$ の吸収は紫 外にかけ，強い吸収となるが，位置は明確にはつかめな い。同時に緑から赤の部分の吸収が幾分浅くなり，色調 は表-2(1) に示すように，No. 2 の青緑から No. 20 の緑にかけ変化する。これと平行の No. 4-8-13-19，712-18の系も,組成による色調の変化は同じ傾向を示す。

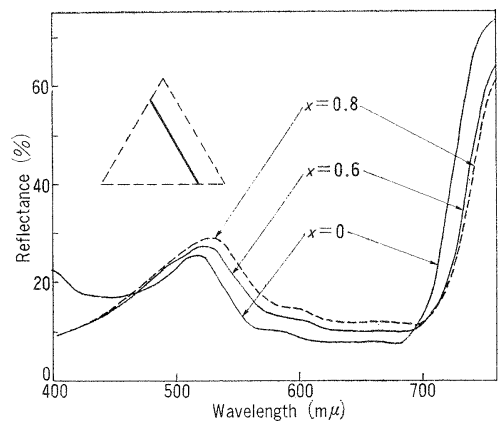

Fig. 14. Reflectance spectra of $0.2 \mathrm{CoO} 1.6$ $\mathrm{MgO} 0.2 \mathrm{Cr}_{2} \mathrm{O}_{3}(0.8-x) \mathrm{SnO}_{2} x \mathrm{TiO}_{2}$

\section{3 色 嬏 試 験}

色釉試験で用いた 3 種の釉の組成を 表-3 に示す。ま た，試験したスピネルは，表-1 および表-2(2) のもの である。

G-1 は石灰带鉛釉で, $\mathrm{ZnO}-\mathrm{Al}_{2} \mathrm{O}_{3}-\mathrm{Cr}_{2} \mathrm{O}_{3}$ 系スピネル のピンク, $\mathrm{ZnO}-\mathrm{Al}_{2} \mathrm{O}_{3}-\mathrm{Cr}_{2} \mathrm{O}_{3}-\mathrm{Fe}_{2} \mathrm{O}_{3}$ 系スピネルの赤茶, 茶が安定に発色する ${ }^{17), 18)}$.

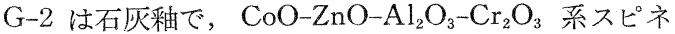
ルのピーコックが，透明で鮮かな呈色をする ${ }^{17), 18)}$. た, $\mathrm{CoO}-(\mathrm{NiO})-\mathrm{MnO}-\mathrm{Fe}_{2} \mathrm{O}_{3}-\mathrm{Cr}_{2} \mathrm{O}_{3}$ 系スピネルの黒, $\mathrm{ZnO}-\mathrm{Al}_{2} \mathrm{O}_{3}-\mathrm{Cr}_{2} \mathrm{O}_{3}-\mathrm{Fe}_{2} \mathrm{O}_{3}$ 系スピネルの茶も, かなり安 定な呈色をする。

Table 3. Composition of glazes.

\begin{tabular}{|c|c|c|}
\hline \multirow{3}{*}{ G-1 } & $0.30 \mathrm{KNaO}$ & \multirow{3}{*}{$0.40 \mathrm{Al}_{2} \mathrm{O}_{3} 3.0 \mathrm{SiO}_{2}$} \\
\hline & $0.30 \mathrm{CaO}$ & \\
\hline & $0.40 \mathrm{ZnO}$ & \\
\hline \multirow{3}{*}{$\mathrm{G}-2$} & $0.30 \mathrm{KNaO}$ & \multirow{3}{*}{$0.40 \mathrm{Al}_{2} \mathrm{O}_{3} 3.5 \mathrm{SiO}_{2}$} \\
\hline & $0.60 \mathrm{CaO}$ & \\
\hline & $0.10 \mathrm{BaO}$ & \\
\hline \multirow{3}{*}{$\mathrm{G}-3$} & $0.20 \mathrm{KNaO}$ & \multirow{3}{*}{$0.80 \mathrm{Al}_{2} \mathrm{O}_{3} 4.0 \mathrm{SiO}_{2}$} \\
\hline & $0.25 \mathrm{CaO}$ & \\
\hline & $0.55 \mathrm{MgO}$ & \\
\hline
\end{tabular}


Table 4. Results of the color glaze test.

(1) Glaze G-1

\begin{tabular}{|c|c|c|c|c|c|c|c|c|}
\hline No. & Composition & $x$ & $y$ & $\lambda_{D}(\mathrm{~m} \mu)$ & $P_{e}(\%)$ & $Y(\%)$ & Color & Result of the X-ray analysis \\
\hline 1 & $\mathrm{M}_{2} \mathrm{~S}$ & 0.315 & 0.323 & 573.3 & 3.1 & 64.8 & yellowish gray & decomp. \\
\hline 2 & $\mathrm{M}_{1.8} \mathrm{~S}_{0.8} \mathrm{Cr}_{0.2}$ & 0.396 & 0.358 & 587.6 & 34.2 & 25.8 & light brown & decomp. \\
\hline 3 & $\mathrm{M}_{2} \mathrm{~S}_{0.8} \mathrm{~T}_{0.2}$ & 0.316 & 0.325 & 571.5 & 3.9 & 65.2 & yellowish gray & decomp. \\
\hline 4 & $\mathrm{M}_{1.6} \mathrm{~S}_{0.6} \mathrm{Cr}_{0 . t}$ & 0.413 & 0.368 & 587.2 & 41.5 & 16.6 & brown & decomp. \\
\hline 5 & $\mathrm{M}_{1.8} \mathrm{~S}_{0.6} \mathrm{~T}_{0.2} \mathrm{Cr}_{0.2}$ & 0.395 & 0.369 & 584.2 & 36.9 & 34.9 & light yellowish brown & decomp. \\
\hline 6 & $\mathrm{M}_{2} \mathrm{~S}_{0.8} \mathrm{~T}_{0.4}$ & 0.319 & 0.329 & 572.5 & 5.8 & 60.3 & yellowish gray & decomp. \\
\hline 7 & $\mathrm{M}_{1.4} \mathrm{~S}_{0.4} \mathrm{Cr}_{0.6}$ & 0.422 & 0.379 & 585.6 & 46.8 & 21.9 & yellowish brown & $\mathrm{S}$ \\
\hline 8 & $\mathrm{M}_{1.6} \mathrm{~S}_{0.4} \mathrm{~T}_{0.2} \mathrm{Cr}_{0,4}$ & 0.428 & 0.378 & 586.6 & 48.2 & 17.6 & light brown & decomp. \\
\hline 9 & $\mathrm{M}_{1.8} \mathrm{~S}_{0.4} \mathrm{~T}_{0.4} \mathrm{Cr}_{0.2}$ & 0.388 & 0.369 & 583.1 & 35.0 & 37.2 & light yellowish brown & decomp. \\
\hline 10 & $\mathrm{M}_{2} \mathrm{~S}_{0.4} \mathrm{~T}_{0.8}$ & 0.325 & 0.335 & 574.3 & 9.0 & 63.6 & pale yellow & decomp. \\
\hline 11 & $\mathrm{M}_{1.2} \mathrm{~S}_{0.2} \mathrm{Cr}_{0.8}$ & 0.399 & 0.371 & 584.3 & 38.5 & 19.1 & yellowish brown & S \\
\hline 12 & $\mathrm{M}_{1.4} \mathrm{~S}_{0.2} \mathrm{~T}_{0.2} \mathrm{Cr}_{0.6}$ & 0.411 & 0.389 & 582.2 & 46.7 & 15.9 & yellowish brown & $\mathrm{s}$ \\
\hline 13 & $\mathrm{M}_{1.6} \mathrm{~S}_{0.2} \mathrm{~T}_{0.4} \mathrm{Cr}_{0.4}$ & 0.428 & 0.390 & 584.2 & 51.4 & 20.4 & yellowish brown & decomp. \\
\hline 14 & $\mathrm{M}_{1.8} \mathrm{~S}_{0.2} \mathrm{~T}_{0.6} \mathrm{Cr}_{0.2}$ & 0.421 & 0.383 & 584.7 & 47.7 & 21.7 & yellowish brown & decomp. \\
\hline 15 & $\mathrm{M}_{2} \mathrm{~S}_{0.2} \mathrm{~T}_{0.6}$ & 0.319 & 0.328 & 572.7 & 5.5 & 67.7 & yellowish gray & decomp. \\
\hline 16 & $\mathrm{MCr}$ & 0.348 & 0.347 & 580.1 & 18.5 & 21.2 & grayish olive & $\mathrm{S}$ \\
\hline 17 & $\mathrm{M}_{1,2} \mathrm{~T}_{0.2} \mathrm{Cr}_{0.8}$ & 0.389 & 0.398 & 577.1 & 13.0 & 11.5 & grayish olive & $\mathrm{s}$ \\
\hline 18 & $\mathrm{M}_{1.4} \mathrm{~T}_{0.4} \mathrm{Cr}_{0.6}$ & 0.395 & 0.394 & 578.8 & 43.5 & 11.7 & grayish olive & $\mathrm{s}$ \\
\hline 19 & $\mathrm{M}_{1.6} \mathrm{~T}_{0.6} \mathrm{Cr}_{0.4}$ & 0.396 & 0.373 & 583.4 & 38.2 & 29.2 & light yellowish brown & $\mathrm{S}$ \\
\hline 20 & $\mathrm{M}_{1.8} \mathrm{~T}_{0.8} \mathrm{Cr}_{0.2}$ & 0.424 & 0.371 & 587.8 & 45.2 & 27.2 & light brown & decomp. \\
\hline 21 & $\mathrm{M}_{2} \mathrm{~T}$ & 0.328 & 0.338 & 574.8 & 10.6 & 57.2 & grayish yellow & decomp. \\
\hline (2) & Glaze G-2 & & & & & & & \\
\hline No. & Composition & $x$ & $y$ & $\lambda_{D}(\mathrm{~m} \mu)$ & $P_{e}(\%)$ & $Y(\%)$ & Color & of the X-ray analysis \\
\hline 1 & $\mathrm{M}_{2} \mathrm{~S}$ & 0.319 & 0.326 & 576.0 & 5.0 & 67.0 & yellowish gray & decomp. \\
\hline 2 & $\mathrm{M}_{1.8} \mathrm{~S}_{0.8} \mathrm{Cr}_{0.2}$ & 0.351 & 0.342 & 584.0 & 17.8 & 20.9 & grayish brown & decomp. \\
\hline 3 & $\mathrm{M}_{2} \mathrm{~S}_{0.8} \mathrm{~T}_{0.2}$ & 0.314 & 0.321 & 575.0 & 2.3 & 65.7 & light brownish gray & decomp. \\
\hline 4 & $\mathrm{M}_{1.6} \mathrm{~S}_{0.6} \mathrm{Cr}_{0.4}$ & 0.382 & 0.331 & 598.3 & 23.2 & 9.3 & grayish brown & $\mathrm{S}$ \\
\hline 5 & $\mathrm{M}_{1.8} \mathrm{~S}_{0.6} \mathrm{~T}_{0.2} \mathrm{Cr}_{0.2}$ & 0.407 & 0.341 & 595.8 & 32.6 & 16.7 & reddish brown & decomp. \\
\hline 6 & $\mathrm{M}_{2} \mathrm{~S}_{0.6} \mathrm{~T}_{0.4}$ & 0.320 & 0.328 & 575.2 & 5.7 & 65.3 & yellowish gray & decomp. \\
\hline 7 & $\mathrm{M}_{1,4} \mathrm{~S}_{0.4} \mathrm{Cr}_{0.6}$ & 0.352 & 0.359 & 577.3 & 22.8 & 13.1 & grayish olive & S \\
\hline 8 & $\mathrm{M}_{1.6} \mathrm{~S}_{0.4} \mathrm{~T}_{0.2} \mathrm{Cr}_{0.4}$ & 0.368 & 0.386 & 575.1 & 34.2 & 16.4 & grayish olive & $\mathrm{S}$ \\
\hline 9 & $\mathrm{M}_{1.8} \mathrm{~S}_{0.4} \mathrm{~T}_{0.4} \mathrm{Cr}_{0.2}$ & 0.357 & 0.383 & 572.9 & 30.5 & 28.1 & grayish yellow & decomp. \\
\hline 10 & $\mathrm{M}_{2} \mathrm{~S}_{0.4} \mathrm{~T}_{0.6}$ & 0.320 & 0.329 & 573.8 & 6.1 & 61.6 & yellowish gray & decomp. \\
\hline 11 & $\mathrm{M}_{1.2 .} \mathrm{S}_{0.2} \mathrm{Cr}_{0.8}$ & 0.359 & 0.385 & 573.0 & 31.3 & 10.1 & grayish olive & $\mathrm{S}$ \\
\hline 12 & $\mathrm{M}_{1.4} \mathrm{~S}_{0.2} \mathrm{~T}_{0.2} \mathrm{Cr}_{0.6}$ & 0.356 & 0.390 & 571.2 & 32.0 & 8.8 & grayish olive & $\mathrm{S}$ \\
\hline 13 & $\mathrm{M}_{1.6} \mathrm{~S}_{0.2} \mathrm{~T}_{0.4} \mathrm{Cr}_{0.4}$ & 0.362 & 0.420 & 568.5 & 41.6 & 9.2 & olive green & $\mathrm{S}$ \\
\hline 14 & $\mathrm{M}_{1.8} \mathrm{~S}_{0.2} \mathrm{~T}_{0.8} \mathrm{Cr}_{0.2}$ & 0.358 & 0.386 & 572.5 & 31.3 & 26.7 & grayish olive & decomp. \\
\hline 15 & $\mathrm{M}_{2} \mathrm{~S}_{0.2} \mathrm{~T}_{0.8}$ & 0.320 & 0.329 & 573.8 & 6.1 & 59.2 & yellowish gray & decomp. \\
\hline 16 & $\mathrm{MCr}$ & 0.350 & 0.379 & 571.4 & 27.3 & 5.4 & dark grayish olive & S \\
\hline 17 & $\mathrm{M}_{1.2} \mathrm{~T}_{0.2} \mathrm{Cr}_{0.8}$ & 0.365 & 0.394 & 572.9 & 35.5 & 7.8 & grayish olive & S \\
\hline 18 & $\mathrm{M}_{1.4} \mathrm{~T}_{0.4} \mathrm{Cr}_{0.6}$ & 0.375 & 0.399 & 574.2 & 39.5 & 12.2 & grayish olive & $\mathrm{S}$ \\
\hline 19 & $\mathrm{M}_{1.6} \mathrm{~T}_{0.6} \mathrm{Cr}_{0.4}$ & 0.379 & 0.407 & 573.9 & 42.8 & 16.9 & olive & $\mathrm{S}$ \\
\hline 20 & $\mathrm{M}_{1.8} \mathrm{~T}_{0.8} \mathrm{Cr}_{0.2}$ & 0.372 & 0.390 & 575.2 & 36.4 & 27.2 & dark olive & decomp. \\
\hline 21 & $\mathrm{M}_{2} \mathrm{~T}$ & 0.321 & 0.330 & 574.3 & 6.6 & 60.5 & yellowish gray & decomp. \\
\hline
\end{tabular}

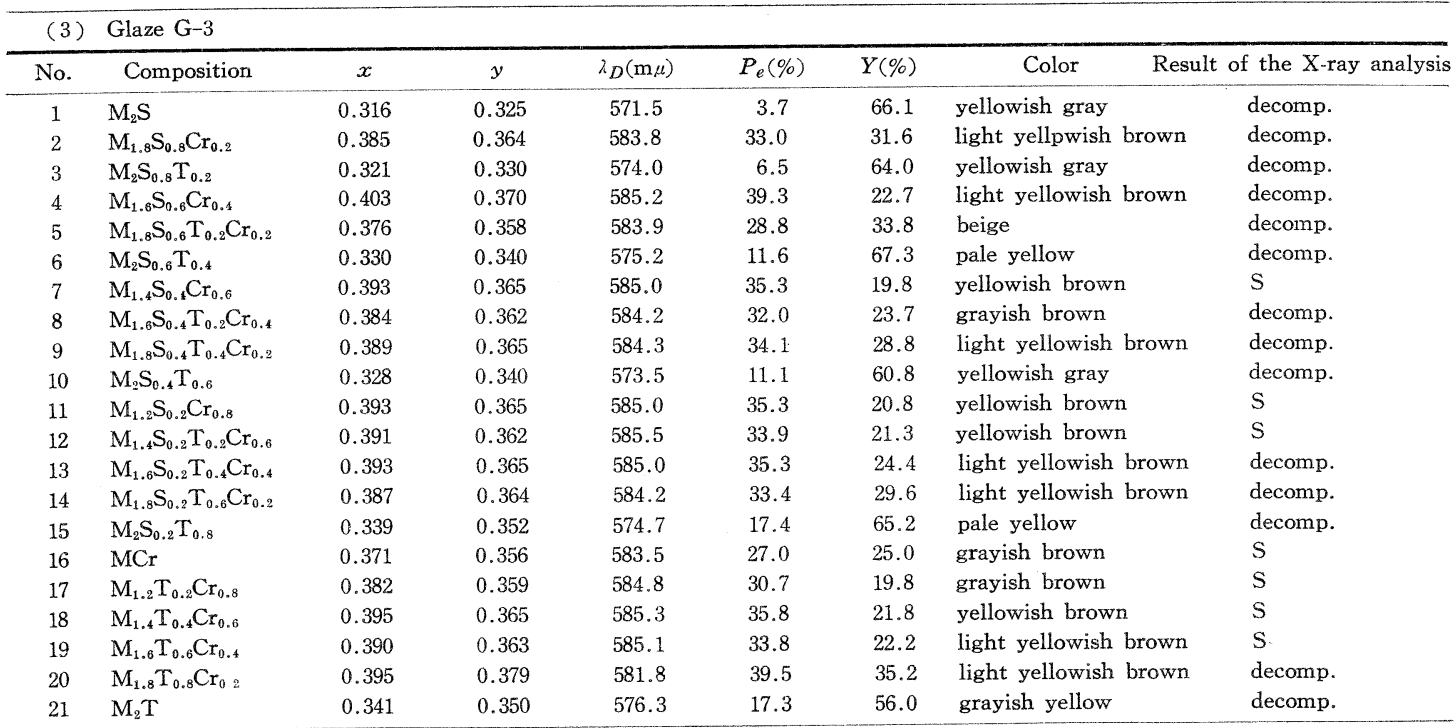


G-3 は，新らしく考案されたマグネシア石灰嬏で， 上記ピーコックが失透し，明かるい青緑に変る ${ }^{17), 18) 。 ~}$

釉に対するスピネル添加量は，いずれも $8 \%$ である.

4.3.1 $\mathrm{MgO}-\mathrm{Cr}_{2} \mathrm{O}_{3}-\mathrm{TiO}_{2}-\mathrm{SnO}_{2}$ 系についての結果

（1）どの釉についても共通していることは，表-4 (1)〜 (3) に示すように, スピネル中の $\mathrm{Cr}^{3+}$ が増すと, いずれもスピネルが釉に対し安定になり, 分解し難くな ることがX線分析の結果認められた。この原因は，まだ 明確にはつかめていないが，ガラスにおいて， $\mathrm{Cr}^{3+}$ が 他の陽イオンと異なり，ガラス中に極めて溶け込み難い ことが大きな要因でないかと考えられる。

(2) G-1, 表-4(1)

(1) No. 1 の $2 \mathrm{MgOSnO}_{2}$ と No. 21 の $2 \mathrm{MgOTiO}_{2}$ に対し, $\mathrm{Mg}^{2+}+\mathrm{Sn}^{4+} \rightleftarrows 2 \mathrm{Cr}^{3+}$ あるいは $\mathrm{Mg}^{2+}+\mathrm{Ti}^{4+} \rightleftarrows$ $2 \mathrm{Cr}^{3+}$ の置換を約 $60 \%$ 以上した組成で，スピネルが 残っていることがX線分析でみとめられた。

(2) $\mathrm{MgO}-\mathrm{Cr}_{2} \mathrm{O}_{3}-\mathrm{SnO}_{2}$ 系 (No. 1-2-4-7-11-16)

No. 1 の白を除き，2-4-7-11 で茶からやや黄をおびた 茶にかけての色調となり，No. 16 で灰味オリーブとな る。

(3) $\mathrm{MgO}-\mathrm{Cr}_{2} \mathrm{O}_{3}-\mathrm{TiO}_{2}$ 系 (No. 16-17-18-20-21) $\mathrm{Cr}^{3+}$ が減少するにつれ，16 $\rightarrow 21$ の方向に灰味オリーブ から茶にかけて色調は変化し，No. 21 で白色となる.

(4) $\mathrm{MgO}-\mathrm{SnO}_{2}-\mathrm{TiO}_{2}$ 系 (No. 1-3-6-10-15-21) ほとんど白色, あるいは極めてらすい黄味灰色である.

(5) $\mathrm{MgO}-\mathrm{Cr}_{2} \mathrm{O}_{3}-\mathrm{TiO}_{2}-\mathrm{SnO}_{2}$ 系 (No. 5-8-9-12-1314） いずれも茶から黄味茶の呈色をする。

(3) G-2, 表-4(2)

(1) この系では, $\mathrm{Mg}^{2+}+\mathrm{Sn}^{4+} \rightleftarrows 2 \mathrm{Cr}^{3+}, \mathrm{Mg}^{2+}+\mathrm{Ti}^{4+}$ $\rightleftarrows 2 \mathrm{Cr}^{3+}$ の置換を約 $40 \%$ 以上した組成で，スピネル のピークが，X線分析の結果みとめられた。この石灰釉 を使用すると光沢がよい。

(2) $\mathrm{MgO}-\mathrm{Cr}_{2} \mathrm{O}_{3}-\mathrm{SnO}_{2}$ 系 (No. 1-2-4-7-11-16)

No. 1 が白色のほか, $\mathrm{Cr}^{3+}$ が増すと, 灰味の強い茶か らオリーブにかけ色調は変化する.No.4 では，後述の No. 5 と同㥞, かなり強いピンクをおびた呈色をした。 $\mathrm{X}$ 線分析で, この両試料中に錫スフェーン $\mathrm{CaO} \mathrm{SnO}_{2}$ $\mathrm{SiO}_{2}$ の生成がみとめられ，これより $\mathrm{G}-2$ の石灰釉によ り，錫スフェーンができ，これにクロムが固溶し，いわ ゆるクロム錫ピンクの発色をしたものと推定される。

(3) $\mathrm{MgO}-\mathrm{Cr}_{2} \mathrm{O}_{3}-\mathrm{TiO}_{2}$ 系 (No. 16-17-18-19-20-21) No. 21 は白色, これに $\mathrm{Cr}^{3+}$ が入り, その量が増すと, 色調は No. 20 $\rightarrow 61$ の方向にオリーブ色から暗いオリー ブ色にかけ変化する.

(4) $\mathrm{MgO}-\mathrm{TiO}_{2}-\mathrm{SnO}_{2}$ 系 (No. 1-3-6-10-15-21) 大体白色である。

(5) $\mathrm{MgO}-\mathrm{Cr}_{2} \mathrm{O}_{3}-\mathrm{TiO}_{2}-\mathrm{SnO}_{2}$ 系 (No. 5-8-9-12-1314）先述のように，No. 5 が赤味をおびた緑のほか，
オリーブ色を示す. 以上 (2)〜 (5) でのオリーブ色は, 沈 んだ緑色であるが，いずれも美しい。

(4) G-3, 表-4(3)

(1) G-1 の場合と同様，No. 1，21 の各スピネルに, $\mathrm{Mg}^{2+}+\mathrm{Sn}^{4+} \rightleftarrows 2 \mathrm{Cr}^{3+}, \mathrm{Mg}^{2+}+\mathrm{Ti}^{4+} \rightleftarrows 2 \mathrm{Cr}^{3+}$ の置換を 大体 $60 \%$ 以上した組成で, スピネルの回折ピークがみ とめられた. 色調は全般的に，G-1 の場合と似ている が, 光沢は劣り, No. 16, 17 付近では, 釉に対する添 加量などを，別途検討する必要がある。

(2) $\mathrm{MgO}-\mathrm{Cr}_{2} \mathrm{O}_{3}-\mathrm{SnO}_{2}$ 系(No. 1-2-4-7-11-16) No. 1 で白色のほか黄味の茶を示しNo.16 で扊味茶となる。

(3) $\mathrm{MgO}-\mathrm{Cr}_{2} \mathrm{O}_{3}-\mathrm{TiO}_{2}$ 系 (No. 16-17-18-19-20-21) No. 21 の白を除き, $\mathrm{Cr}^{3+}$ が増すと, No. $20 \rightarrow 16$ の方 向に明かるい黄味茶から扊味茶にかけ, 色調の変化がみ られる。

(4) $\mathrm{MgO}-\mathrm{TiO}_{2}-\mathrm{SnO}_{2}$ 系 (No. 1-3-6-10-15-21)

ほとんど白に近い色調である。

(5) $\mathrm{MgO}-\mathrm{Cr}_{2} \mathrm{O}_{3}-\mathrm{TiO}_{2}-\mathrm{SnO}_{2}$ 系 (No. 5-8-9-12-1314）No. 5 のベージュから明るい黄味茶にかけ色調 は変化する。この G-1, G-3 の各釉で得られた茶系統 の呈色は, $\mathrm{ZnO}-\mathrm{Al}_{2} \mathrm{O}_{3}-\mathrm{Cr}_{2} \mathrm{O}_{3}-\mathrm{Fe}_{2} \mathrm{O}_{3}$ 系スピネルでの色 釉試験で見られる茶系統の色ほど赤味はないが, いずれ も安定なものである。

4.3.2 $\mathrm{CoO}-\mathrm{MgO}-\mathrm{Cr}_{2} \mathrm{O}_{3}-\mathrm{TiO}_{2}-\mathrm{SnO}_{2}$ 系についての 結果 (1) $\mathrm{Co}^{2+}$ を含むこの系も，4.3.1 項と同様， $\mathrm{Cr}^{3+}$ が増すに従い，スピネルが釉に対し安定になるこ とが，X線分析でみとめられた。

(2) G-1, 表 $-5(1)$

(1) $\mathrm{CoO}-\mathrm{MgO}-\mathrm{Cr}_{2} \mathrm{O}_{3}-\mathrm{SnO}_{2}$ 系 (No. 1-2-4-7-11-16) No. 1 の $0.5 \mathrm{CoO} 1.5 \mathrm{MgOSnO}_{2}$, No. 21 の $0.5 \mathrm{CoO}$ $1.5 \mathrm{MgOTiO}_{2}$ に, $\mathrm{Mg}^{2+}+\mathrm{Sn}^{4+} \rightleftarrows 2 \mathrm{Cr}^{3+}, \mathrm{Mg}^{2+}+\mathrm{Ti}^{4+}$ $\rightleftarrows 2 \mathrm{Cr}^{3+}$ の置換を約 $60 \%$ 以上した組成から，スピネ ルが残っていることがみとめられた．No.1 は分解のた め, 色調は大きく赤により, 紫味青となる.このセルリ アンの色を安定に焼付けするのには，さらに釉の検討が 必要である.No.4〜16 はやや暗い緑から青緑にかけて の呈色である。

(2) $\mathrm{CoO}-\mathrm{MgO}-\mathrm{Cr}_{2} \mathrm{O}_{3}-\mathrm{TiO}_{2}$ 系 (No. 16-17-18-1920-21) No. 21 の $0.5 \mathrm{CoO} 1.5 \mathrm{MgOTiO}_{2}$ は分解の ため No. 1 同様, 色調は大きく赤により，紫味青とな る.このスピネルに $\mathrm{Cr}^{3+}$ が入ると，No. 21 $\rightarrow 16$ の方 向に緑青からオリーブ 緑, 暗い黄緑と色調は変化し, No. 16 の青緑になる.

(3) $\mathrm{CoO}-\mathrm{MgO}-\mathrm{TiO}_{2}-\mathrm{SnO}_{2}$ 系 (No. 1-3-6-10-15-21) 全試料分解し，いずれも紫味青を示す（2）で述べたよ うに, この系のスピネルには釉の検討が必要である。

(4) $\mathrm{CoO}-\mathrm{MgO}-\mathrm{Cr}_{2} \mathrm{O}_{3}-\mathrm{TiO}_{2}-\mathrm{SnO}_{2}$ 系 (No. 5-8-912-13-14）Ｃr $\mathrm{Cr}^{3+}$ の多い No. 8, 12, 13 が緑から暗 
(1) Glaze G-1

Table 5. Results of the color glaze test.

\begin{tabular}{|c|c|c|c|c|c|c|c|c|}
\hline No. & Composition & $x$ & $y$ & $\lambda_{D}(\mathrm{~m} \mu)$ & $P_{e}(\%)$ & $Y(\%)$ & Color & Result of the X-ray analysis \\
\hline 1 & $\mathrm{C}_{0.5} \mathrm{M}_{1.5} \mathrm{~S}$ & 0.235 & 0.223 & 473.2 & 39.6 & 17.3 & strong purplish blue & decomp. \\
\hline 2 & $\mathrm{C}_{0.5} \mathrm{M}_{1.8} \mathrm{~S}_{0.8} \mathrm{Cr}_{0.2}$ & 0.248 & 0.276 & 482.7 & 26.9 & 5.1 & dark greenish blue & decomp. \\
\hline 3 & $\mathrm{C}_{0}{ }_{5} \mathrm{M}_{1.5} \mathrm{~S}_{0.8} \mathrm{~T}_{0.2}$ & 0.237 & 0.224 & 472.7 & 37.7 & 17.8 & strong purplish blue & decomp. \\
\hline 4 & $\mathrm{C}_{0.5} \mathrm{M}_{1.8} \mathrm{~S}_{0.8} \mathrm{Cr}_{0.4}$ & 0.289 & 0.333 & 500.8 & 7.0 & 9.1 & grayish green & decomp. \\
\hline 5 & $\mathrm{C}_{0.5} \mathrm{M}_{1.8} \mathrm{~S}_{0.8} \mathrm{~T}_{0.2} \mathrm{Cr}_{0.2}$ & 0.263 & 0.298 & 496.2 & 19.1 & 10.5 & dull greenish blue & decomp. \\
\hline 6 & $\mathrm{C}_{0.5} \mathrm{M}_{1.5} \mathrm{~S}_{\ell .6} \mathrm{~T}_{0.4}$ & 0.241 & 0.227 & 472.1 & 36.0 & 16.4 & strong purplish blue & decomp. \\
\hline 7 & $\mathrm{C}_{0.5} \mathrm{M}_{0.8} \mathrm{~S}_{0.4} \mathrm{Cr}_{0.6}$ & 0.276 & 0.353 & 504.6 & 11.2 & 4.5 & dark green & $\mathrm{s}$ \\
\hline 8 & $\mathrm{C}_{0.5} \mathrm{M}_{1.2} \mathrm{~S}_{0.4} \mathrm{~T}_{0.2} \mathrm{Cr}_{0.4}$ & 0.283 & 0.342 & 503.0 & 8.9 & 6.0 & dark green & $\mathrm{S}$ \\
\hline 9 & $\mathrm{C}_{0.5} \mathrm{M}_{1.88} \mathrm{~S}_{0.4} \mathrm{~T}_{0.4} \mathrm{Cr}_{0.2}$ & 0.265 & 0.297 & 485.7 & 18.5 & 9.6 & grayish blue & decomp. \\
\hline 10 & $\mathrm{C}_{0.5} \mathrm{M}_{1.5} \mathrm{~S}_{0.4} \mathrm{~T}_{0.6}$ & 0.237 & 0.224 & 472.8 & 37.8 & 14.3 & dull purplish blue & decomp. \\
\hline 11 & $\mathrm{C}_{0.5} \mathrm{M}_{0.7} \mathrm{~S}_{0.2} \mathrm{Cr}_{0.8}$ & 0.275 & 0.336 & 497.8 & 12.0 & 8.3 & dull bluish green & $\mathrm{s}$ \\
\hline 12 & $\mathrm{C}_{0.5} \mathrm{M}_{0.8} \mathrm{~S}_{0.2} \mathrm{~T}_{0.2} \mathrm{Cr}_{0.6}$ & 0.286 & 0.338 & 502.3 & 7.9 & 10.4 & grayish green & $\mathrm{s}$ \\
\hline 13 & $\mathrm{C}_{0.5} \mathrm{M}_{1.1 .1} \mathrm{~S}_{0.2} \mathrm{~T}_{0.4} \mathrm{Cr}_{0.4}$ & 0.310 & 0.382 & 551.0 & 17.8 & 5.4 & dark yellowish green & $\mathrm{S}$ \\
\hline 14 & $\mathrm{C}_{0.5} \mathrm{M}_{1.8} \mathrm{~S}_{0.2} \mathrm{~T}_{0.6} \mathrm{Cr}_{0.2}$ & 0.284 & 0.328 & 496.5 & 9.0 & 6.6 & dark bluish green & $\mathrm{S}$ \\
\hline 15 & $\mathrm{C}_{0.5} \mathrm{M}_{1.5} \mathrm{~S}_{0.8} \mathrm{~T}_{0.8}$ & 0.236 & 0.219 & 471.8 & 39.0 & 13.7 & dull purplish blue & decomp. \\
\hline 16 & $\mathrm{C}_{0.5} \mathrm{M}_{0.5} \mathrm{Cr}$ & 0.235 & 0.311 & 490.2 & 29.3 & 8.5 & dull blue green & $\mathrm{s}$ \\
\hline 17 & $\mathrm{C}_{0.3} \mathrm{M}_{0.7} \mathrm{~T}_{0.2} \mathrm{Cr}_{0.8}$ & 0.312 & 0.379 & 552.6 & 17.5 & 4.3 & dark yellowish green & $\mathrm{S}$ \\
\hline 18 & $\mathrm{C}_{0.5} \mathrm{M}_{0.8} \mathrm{~T}_{0.4} \mathrm{Cr}_{0.6}$ & 0.327 & 0.385 & 561.2 & 23.0 & 4.2 & dark grayish olive green & $\mathrm{s}$ \\
\hline 19 & $\mathrm{C}_{0.5} \mathrm{M}_{1.1} \mathrm{~T}_{0.6} \mathrm{Cr}_{0.4}$ & 0.318 & 0.371 & 557.8 & 16.8 & 3.5 & dark grayish olive green & $\mathrm{S}$ \\
\hline 20 & $\mathrm{C}_{0.5} \mathrm{M}_{1.8} \mathrm{~T}_{0.8} \mathrm{Cr}_{0.2}$ & 0.262 & 0.295 & 485.5 & 19.8 & 4.6 & dark greenish blue & $\mathrm{s}$ \\
\hline 21 & $\mathrm{C}_{0.5} \mathrm{M}_{1.5} \mathrm{~T}$ & 0.236 & 0.210 & 469.0 & 40.5 & 12.9 & dull purplish blue & decomp. \\
\hline
\end{tabular}

(2) Glaze G-2

\begin{tabular}{|c|c|c|c|c|c|c|c|c|}
\hline No. & Composition & $x$ & $y$ & $\lambda_{D}(\mathrm{~m} \mu)$ & $P_{e}(\%)$ & $Y(\%)$ & Color & Result of the X-ray analysis \\
\hline 1 & $\mathrm{C}_{0.5} \mathrm{M}_{1.5} \mathrm{~S}$ & 0.213 & 0.161 & 464.8 & 56.0 & 7.3 & strong violet & decomp. \\
\hline 2 & $\mathrm{C}_{0.5} \mathrm{M}_{\mathrm{x} .3} \mathrm{~S}_{0.8} \mathrm{Cr}_{0.2}$ & 0.209 & 0.220 & 478.3 & 47.7 & 3.6 & dark blue & decomp. \\
\hline 3 & $\mathrm{C}_{0.3} \mathrm{M}_{1.5} \mathrm{~S}_{0.8} \mathrm{~T}_{0.8}$ & 0.198 & 0.126 & 461.2 & 66.8 & 3.7 & deep violet & decomp. \\
\hline 4 & $\mathrm{C}_{0.5} \mathrm{M}_{1.1} \mathrm{~S}_{0.6} \mathrm{Cr}_{0.4}$ & 0.198 & 0.244 & 482.8 & 48.5 & 3.1 & dark greenish blue & decomp. \\
\hline 5 & $\mathrm{C}_{0.5} \mathrm{M}_{1.8} \mathrm{~S}_{0.6} \mathrm{~T}_{0.2} \mathrm{Cr}_{0.2}$ & 0.210 & 0.222 & 478.5 & 47.1 & 3.6 & dark blue & decomp. \\
\hline 6 & $\mathrm{C}_{0.5} \mathrm{M}_{1.5} \mathrm{~S}_{0.6} \mathrm{~T}_{0.4}$ & 0.209 & 0.161 & 466.3 & 57.0 & 6.8 & deep purplish blue & decomp. \\
\hline 7 & $\mathrm{C}_{0.5} \mathrm{M}_{0.8} \mathrm{~S}_{0.4} \mathrm{Cr}_{0.6}$ & 0.203 & 0.285 & 487.4 & 42.5 & 3.5 & dark blue green & $\mathrm{S}$ \\
\hline 8 & $\mathrm{C}_{0.5} \mathrm{M}_{8.8} \mathrm{~S}_{0.4} \mathrm{~T}_{0.2} \mathrm{Cr}_{0.4}$ & 0.198 & 0.257 & 484.4 & 47.2 & 3.7 & dark greenish blue & decomp. \\
\hline 9 & $\mathrm{C}_{0.5} \mathrm{M}_{1,8} \mathrm{~S}_{0.4} \mathrm{~T}_{0.4} \mathrm{Cr}_{0.2}$ & 0.218 & 0.220 & 476.7 & 44.7 & 2.6 & dark blue & decomp. \\
\hline 10 & $\mathrm{C}_{0.5} \mathrm{M}_{1.5} \mathrm{~S}_{0.4} \mathrm{~T}_{0.6}$ & 0.203 & 0.152 & 466.6 & 60.5 & 5.9 & deep purplish blue & decomp. \\
\hline 11 & $\mathrm{C}_{0.5} \mathrm{M}_{0.7} \mathrm{~S}_{0.2} \mathrm{Cr}_{0.8}$ & 0.197 & 0.287 & 487.8 & 44.5 & 3.5 & dark blue green & $\mathrm{S}$ \\
\hline 12 & $\mathrm{C}_{0.3} \mathrm{M}_{0.9} \mathrm{~S}_{0.2} \mathrm{~T}_{0.2} \mathrm{Cr}_{0.8}$ & 0.194 & 0.279 & 487.0 & 46.4 & 3.8 & dark blue green & $\mathrm{S}$ \\
\hline 13 & $\mathrm{C}_{0.5} \mathrm{M}_{1.3 .1} \mathrm{~S}_{0.8} \mathrm{~T}_{0.4} \mathrm{Cr}_{0.4}$ & 0.210 & 0.282 & 486.7 & 40.2 & 3.6 & dark blue green & $\mathrm{S}$ \\
\hline 14 & $\mathrm{C}_{0.5} \mathrm{M}_{1.8} \mathrm{~S}_{0.2} \mathrm{~T}_{0.8} \mathrm{Cr}_{0.2}$ & 0.210 & 0.237 & 480.7 & 45.2 & 3.0 & dark greenish blue & $\mathrm{S}$ \\
\hline 15 & $\mathrm{C}_{0.5} \mathrm{M}_{1.3} \mathrm{~S}_{0.2} \mathrm{~T}_{0.8}$ & 0.207 & 0.160 & 467.0 & 57.7 & 6.5 & deep purplish blue & decomp. \\
\hline 16 & $\mathrm{C}_{0.3} \mathrm{M}_{0.5} \mathrm{Cr}$ & 0.220 & 0.304 & 489.3 & 34.5 & 4.1 & dark blue green & $\mathrm{S}$ \\
\hline 17 & $\mathrm{C}_{0.5} \mathrm{M}_{0.7} \mathrm{~T}_{0.2} \mathrm{Cr}_{0.8}$ & 0.217 & 0.315 & 490.8 & 34.7 & 2.5 & dark blue green & $\mathrm{S}$ \\
\hline 18 & $\mathrm{C}_{0.5} \mathrm{M}_{0.9} \mathrm{~T}_{0.4} \mathrm{Cr}_{0.8}$ & 0.217 & 0.299 & 488.7 & 36.0 & 2.6 & dark blue green & $\mathrm{S}$ \\
\hline 19 & $\mathrm{C}_{0.5} \mathrm{M}_{1.2} \mathrm{~T}_{0.6} \mathrm{Cr}_{0.4}$ & 0.226 & 0.288 & 486.8 & 33.7 & 1.8 & dark blue green & $S$ \\
\hline 20 & $\mathrm{C}_{0.5} \mathrm{M}_{1.8} \mathrm{~T}_{0.8} \mathrm{Cr}_{0.2}$ & 0.216 & 0.233 & 479.4 & 43.3 & 1.9 & dark blue & decomp. \\
\hline 21 & $\mathrm{C}_{0.5} \mathrm{M}_{1.5} \mathrm{~T}$ & 0.186 & 0.101 & 459.8 & 75.0 & 2.2 & deep purplish blue & decomp. \\
\hline
\end{tabular}

(3) Glaze $\mathrm{G}-3$

\begin{tabular}{|c|c|c|c|c|c|c|c|c|}
\hline No. & Composition & $x$ & $y$ & $\lambda_{D}(\mathrm{~m} \mu)$ & $P_{e}(\%)$ & $Y(\%)$ & Color & Result of the X-ray analysis \\
\hline 1 & $\mathrm{C}_{0.5} \mathrm{M}_{1.5} \mathrm{~S}$ & 0.243 & 0.226 & 471.1 & 35.6 & 15.6 & strong purplish blue & decomp. \\
\hline 2 & $\mathrm{C}_{0.5} \mathrm{M}_{1.8} \mathrm{~S}_{0.8} \mathrm{Cr}_{0.2}$ & 0.230 & 0.265 & 482.8 & 34.7 & 8.1 & dull greenish blue & decomp. \\
\hline 3 & $\mathrm{C}_{0.5} \mathrm{M}_{1.5} \mathrm{~S}_{0.8} \mathrm{~T}_{0.2}$ & 0.232 & 0.198 & 467.0 & 43.7 & 9.0 & strong purplish blue & decomp. \\
\hline 4 & $\mathrm{C}_{0.5} \mathrm{M}_{1,1} \mathrm{~S}_{0.8} \mathrm{Cr}_{0.4}$ & 0.218 & 0.287 & 487.1 & 36.7 & 3.5 & dark blue green & $\mathrm{S}$ \\
\hline 5 & $\mathrm{C}_{0.5} \mathrm{M}_{1.8} \mathrm{~S}_{0.6} \mathrm{~T}_{0.2} \mathrm{Cr}_{0.2}$ & 0.221 & 0.260 & 483.0 & 38.5 & 6.3 & dark greenish blue & decomp. \\
\hline 6 & $\mathrm{C}_{0.5} \mathrm{M}_{1.5} \mathrm{~S}_{0.8} \mathrm{~T}_{0.4}$ & 0.224 & 0.180 & 465.0 & 49.3 & 6.0 & deep purplish blue & decomp. \\
\hline 7 & $\mathrm{C}_{0.5} \mathrm{M}_{0.9} \mathrm{~S}_{0.4} \mathrm{Cr}_{0.8}$ & 0.228 & 0.317 & 491.1 & 30.5 & 3.7 & dark blue green & $\mathrm{S}$ \\
\hline 8 & $\mathrm{C}_{0.5} \mathrm{M}_{1,1} \mathrm{~S}_{0.4} \mathrm{~T}_{0.2} \mathrm{Cr}_{0.4}$ & 0.216 & 0.281 & 486.4 & 38.0 & 4.6 & dark blue green & S \\
\hline 9 & $\mathrm{C}_{0.5} \mathrm{M}_{1.8} \mathrm{~S}_{0.4} \mathrm{~T}_{0.4} \mathrm{Cr}_{0.2}$ & 0.215 & 0.257 & 483.1 & 41.0 & 4.7 & dark greenish blue & decomp. \\
\hline 10 & $\mathrm{C}_{0.5} \mathrm{M}_{1,5} \mathrm{~S}_{0.4} \mathrm{~T}_{0.6}$ & 0.227 & 0.191 & 467.3 & 46.5 & 6.9 & deep purplish blue & decomp. \\
\hline 11 & $\mathrm{C}_{0.5} \mathrm{M}_{0.7} \mathrm{~S}_{0.2} \mathrm{Cr}_{0.8}$ & 0.227 & 0.308 & 489.8 & 31.5 & 4.8 & dark blue green & $\mathrm{S}$ \\
\hline 12 & $\mathrm{C}_{0.5} \mathrm{M}_{0.9} \mathrm{~S}_{0.2} \mathrm{~T}_{0.2} \mathrm{Cr}_{0.6}$ & 0.225 & 0.295 & 487.9 & 33.3 & 5.3 & dark blue green & $\mathrm{S}$ \\
\hline 13 & $\mathrm{C}_{0.5} \mathrm{M}_{1.1} \mathrm{~S}_{0.2} \mathrm{~T}_{0.4} \mathrm{Cr}_{0.4}$ & 0.210 & 0.270 & 485.3 & 41.3 & 4.1 & dark greenish blue & $\mathrm{S}$ \\
\hline 14 & $\mathrm{C}_{0.5} \mathrm{M}_{1.3} \mathrm{~S}_{0.2} \mathrm{~T}_{0.6} \mathrm{Cr}_{0.2}$ & 0.213 & 0.249 & 482.2 & 42.6 & 5.7 & dark greenish blue & $\mathrm{S}$ \\
\hline 15 & $\mathrm{C}_{0.5} \mathrm{M}_{1.5} \mathrm{~S}_{0.2} \mathrm{~T}_{0.8}$ & 0.226 & 0.190 & 467.3 & 46.9 & 6.0 & deep purplish blue & decomp. \\
\hline 16 & $\mathrm{C}_{0.3} \mathrm{M}_{0.3} \mathrm{Cr}$ & 0.264 & 0.313 & 490.2 & 17.4 & 11.9 & dull blue green & $\mathrm{S}$ \\
\hline 17 & $\mathrm{C}_{0.5} \mathrm{M}_{0.7} \mathrm{~T}_{0.2} \mathrm{Cr}_{0.8}$ & 0.269 & 0.309 & 488.8 & 5.9 & 10.2 & grayish green & $\mathrm{S}$ \\
\hline 18 & $\mathrm{C}_{0.5} \mathrm{M}_{0.9} \mathrm{~T}_{0.4} \mathrm{Cr}_{0.6}$ & 0.264 & 0.303 & 487.5 & 8.2 & 12.9 & dull greenish blue & $\mathrm{S}$ \\
\hline 19 & $\mathrm{C}_{0.5} \mathrm{M}_{1,1} \mathrm{~T}_{0.6} \mathrm{Cr}_{0.4}$ & 0.244 & 0.282 & 484.5 & 27.7 & 7.7 & dull greenish blue & $\mathrm{S}$ \\
\hline 20 & $\mathrm{C}_{0.3} \mathrm{M}_{1.8} \mathrm{~T}_{0.8} \mathrm{Cr}_{0.2}$ & 0.210 & 0.243 & 481.6 & 44.3 & 4.4 & dark greenish blue & decomp. \\
\hline 21 & $\mathrm{C}_{0.5} \mathrm{M}_{1.5} \mathrm{~T}$ & 0.220 & 0.181 & 467.4 & 50.2 & 4.8 & dark purplish blue & decomp. \\
\hline
\end{tabular}


い黄緑にかけての呈色をする. No. 7, 11〜13, 17〜19 などで得られた緑の色調は，やや暗いものではあるが美 しい.この系では, $\mathrm{MgO}$ 系のスピネルに帚鉛釉を使用 したため, $\mathrm{Mg}^{2+} \rightarrow \mathrm{Zn}^{2+}$ の置換で, 新らしく $\mathrm{ZnO}$ 系 スピネルが生成したことも推定される。しかし， ZnO 系スピネルと，むとの $\mathrm{MgO}$ 系スピネルとでは，格子定 数の差が僅少のため, X線分析だけでは断定できない， この点はさらに今後の検討が必要である.

(3) G-2，表-5(2)

(1) この G-2 では, 全域で光沢が非常によく, 色調 む鮮明である、スピネルは G-1 の場合より，さらにチ タンスピネル側にも, 分解しないで残っているのがみと められた。

(2) $\mathrm{CoO}-\mathrm{MgO}-\mathrm{Cr}_{2} \mathrm{O}_{3}-\mathrm{SnO}_{2}$ 系 (No. 1-2-4-7-11-16) No. 1 は分解し, 紫色を示すが, $\mathrm{Cr}^{3+}$ が入ると, 暗い 青から緑青, 青緑へと色調は変化するが, とくに No. 4, 7，11，16 は，美しいピーコック（青緑）の色調を示す.

(3) $\mathrm{CoO}-\mathrm{MgO}-\mathrm{Cr}_{2} \mathrm{O}_{3}-\mathrm{TiO}_{2}$ 系 (No. 16-17-18-1920-21） No. 21 は分解し, 鮮明な紫味青を示す.こ れに $\mathrm{Cr}^{3+}$ が入ると，No. 20 $\rightarrow 16$ の方向で，暗い青か ら青緑へと色調は変化するが，No. 17〜19 はとくに美 ᄂい.

(4) $\mathrm{CoO}-\mathrm{MgO}-\mathrm{TiO}_{2}-\mathrm{SnO}_{2}$ 系 (No. 1-3-6-10-15-21) 全試料分解するが，いずれも鮮明な紫から紫味青を示す。

(5) $\mathrm{CoO}-\mathrm{MgO}-\mathrm{Cr}_{2} \mathrm{O}_{3}-\mathrm{TiO}_{2}-\mathrm{SnO}_{2}$ 系 (5-8-9-12-1314） No. 5 の暗い青加, 緑青, 青緑にかけ色調は 変化する.とくに No. 8, 12, 13 は美しい。

要するに, この場合はかなり広い範囲で, 鮮明なピー コックに似た色調を示しているのが大きな特徴である.

(4) G-3，表-5(3)

(1) X線分析で，スピネルは G-1 の場合と大体同じ 組成の範囲で残っているのがみとめられた，G-3 では， G-2 の石灰釉の場合より光沢は劣るが，色調は全般に 明かるいのが特徴である.

(2) $\mathrm{CoO}-\mathrm{MgO}-\mathrm{Cr}_{2} \mathrm{O}_{3}-\mathrm{SnO}_{2}$ 系 (No. 1-2-4-7-11-16)

No. 1 は分解, 紫味青となるが, これに $\mathrm{Cr}^{3+}$ が入る と, 緑青から青緑にかけての色調の変化がみられる。と くに No. 4, 7, 11 は美しい. No. 16 は後述の No. 17, 18 とともに, 釉に対する配合の割合, 加熱温度など検 討する必要がある.

(3) $\mathrm{CoO}-\mathrm{MgO}-\mathrm{Cr}_{2} \mathrm{O}_{3}-\mathrm{TiO}_{2}$ 系 (No. 16-17-18-1920-21） No. 21 汾分解, No. 1 同様, 紫味青となる

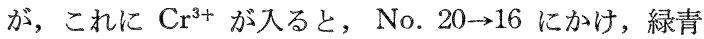
加ら青緑に色調は変化する。

(4) $\mathrm{CoO}-\mathrm{MgO}-\mathrm{TiO}_{2}-\mathrm{SnO}_{2}$ 系 (No. 1-3-6-10-15-21) 全試料分解し，紫味青となるが，G-2 の場合ほど鮮明 な色調ではない。
窒業協会誌 82 [2] 1974125

(5) $\mathrm{CoO}-\mathrm{MgO}-\mathrm{Cr}_{2} \mathrm{O}_{3}-\mathrm{TiO}_{2}-\mathrm{SnO}_{2}$ 系 (No. 5-8-912-13-14） 緑青から 青緑にかけ色調は変化するが， いずれも鮮明で，とくに No. 8，12，13 は美しい。

この G-3 の場合も，かなり広い範囲でピーコックに 似た鮮明な緑の色調を得た。

\section{5. 結語}

以上，実験結果を要約すれば，次のようである.

(1) 多数の新らしい $(\mathrm{CoO})-\mathrm{MgO}-\mathrm{Cr}_{2} \mathrm{O}_{3}-\mathrm{TiO}_{2}-$ $\mathrm{SnO}_{2}$ 系の多成分単一スピネルを得を.とくに, $\mathrm{Co}^{2+}$ を 含む系では, 青から青緑にかけての鮮明な色が得られた が，多成分系での緑色はとくに美しい。

(2) 色釉試験の結果, $\mathrm{MgO}-\mathrm{Cr}_{2} \mathrm{O}_{3}-\mathrm{TiO}_{2}-\mathrm{SnO}_{2}$ 系

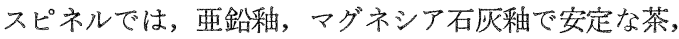
石灰嬏では，暗い緑の呈色を得た。 $\mathrm{CoO}-\mathrm{MgO}-\mathrm{Cr}_{2} \mathrm{O}_{3}$ $\mathrm{TiO}_{2}-\mathrm{SnO}_{2}$ 系スピネルでは，业鉛嬏でやや暗い色調の 緑, 石灰嬏, マグネシア石灰嬏で, 広い範囲でピーコッ クに似た鮮明な呈色を得た。

（3）従来，陶磁器用スピネル顔料は，ほとんど亜鉛 系スピネルが使用されてきた。本研究で調製したマグネ シウム系スピネルは，従来から用いられていた釉で十分 使用できることが確認された。

謝 辞 本研究を行なうに当り，色釉試験につき，工業技 術院名古屋工業技術試験所第 6 部部長 加藤悦三氏の 愁切なご 指導を賜わったことを記し，同氏に厚く感謝の意を表する。

\section{文献}

1）大塚 淳, 笘協 70 [4] 110-13 (1962).

2）大塚 淳, 窯協 73 [8] 170-80 (1965).

3）大塚 淳, 窯協 73 [9] 196-206 (1965).

4) 大塚 淳, 窯協 73 [11] 225-35 (1965).

5）大塚 淳, 窯協 74 [3] 68-83 (1966).

6）大塚 淳, 墨協 74 [5] 153 -65 (1966).

7) 大塚 淳, 窯協 80 [7] 285-99 (1972).

8）山口悟郎，富浦煌詞，田辺 漠, 䇺協 62 [693] 191-96 (1954).

9) J.B. Goodenough, A.L. Leob, Phys. Rev. 99, 381408 (1955).

10) A. Navrotsky, O.J. Kleppa, J. inorg. nucl. Chem. 29, 2701-14 (1967).

11) A. Miller, J. Appl. Phys. 30 [4] 24 S-25 S (1959).

12) D. Reinen, O.S. DuMont, Z. Anorg. Allgem. Chem. 312, 121-34 (1961).

13) O.S. DuMont, D. Reinen, Z. Elektrochem. 63, 97887 (1959)

14) O.S. DuMont, Forschungsberichte des Wirtschafts. und Verkehrsministeriums Nordrhein-Westfalen, [193] 5-39 (1955).

15）山口悟郎, 宮部久子, 工化 63 [4] 562-65 (1962).

16) O.S. DuMont, H. Brokopf, K. Burkhardt, Z. anorg. allgem. Chem. 295, 7-35 (1958).

17）加藤悦三, “陶磁器の装飾技術”宰技社 (1967) p. 87-89.

18）大绿 淳, 等協 81 [2] 11-25 (1973).

(5/11/1973 受付) 